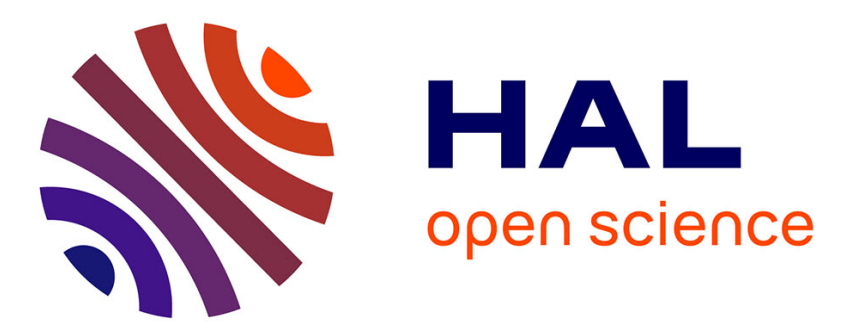

\title{
The political map of Arabia and the Middle East in the 3rd century AD revealed by a Sabaean inscription - a view from the South
}

\author{
Jérémie Schiettecatte, Mounir Arbach
}

\section{- To cite this version:}

Jérémie Schiettecatte, Mounir Arbach. The political map of Arabia and the Middle East in the 3rd century AD revealed by a Sabaean inscription - a view from the South. Arabian Archaeology and Epigraphy, 2016, 27 (2), pp.176-196. 10.1111/aae.12071 . halshs-01388356

\section{HAL Id: halshs-01388356 \\ https://shs.hal.science/halshs-01388356}

Submitted on 26 Oct 2016

HAL is a multi-disciplinary open access archive for the deposit and dissemination of scientific research documents, whether they are published or not. The documents may come from teaching and research institutions in France or abroad, or from public or private research centers.
L'archive ouverte pluridisciplinaire HAL, est destinée au dépôt et à la diffusion de documents scientifiques de niveau recherche, publiés ou non, émanant des établissements d'enseignement et de recherche français ou étrangers, des laboratoires publics ou privés. 


\title{
The political map of Arabia and the Middle East in the 3rd century AD revealed by a Sabaean inscription - a view from the South.
}

\author{
Jérémie SCHIETTECATTE \& Mounir ARBACH
}

\begin{abstract}
An inscription in Sabaic recently discovered on the site of Jabal Riyām (Yemen) gives an account of a journey - probably a diplomatic mission — carried out by a Sabaean dignitary on behalf of the rulers of the tribe of Humlann. He listed the territories he passed through in western and northern Arabia and in the Middle East, up to Palmyra and Mesopotamia. This text, assumed to date back to the 3rd century AD (more probably c.260-280), provides a unique picture of the political forces in the area and throws new light on the regional map of the time.
\end{abstract}

\section{Introduction}

The accuracy of the political map of ancient Arabia varies according to the period. From the 3rd century $\mathrm{BC}$ to the early 2 nd century $\mathrm{AD}$, the outlines of the political entities interacting within the Peninsula are documented in detail in classical sources: the Geography by Eratosthenes of Cyrene (3rd century BC), by Strabo (1st century BC), and by Claudius Ptolemy (early 2nd century AD); Pliny's Natural History and the Periplus Maris Erythraei (CASSON 1989) by an unknown author (both from the 1st century AD). From the second half of the 4th to the mid-6th century AD, a detailed picture of the political powers is provided by both the classical sources (Roman History by Ammianus Marcellinus, Church History by Philostorgius, History of the Wars by Procopius of Caesarea) and the accounts of military deeds by the kings of Himyar and their vassals in the Sabaic inscriptions.

The intermediate period (mid-2nd-mid-4th century), however, did not yield any document providing us with a global view of the political landscape, and it was only by comparing various sources (Nabataean, Palmyrene, South Arabian, Ge'ez, and Latin inscriptions) that a rough sketch of a political map of Arabia could be drawn. This shaded area now emerges from obscurity thanks to the discovery by one of the present authors, in 2006, of a rare document from the ancient kingdom of Saba' (Yemen), inscription Jabal Riyām 2006-17 (hereafter Riyām 2006-17). This Sabaic inscription from a temple on Jabal Riyām and dated to the 3rd century AD, is an account of a diplomatic mission of the kingdom of Saba' to the northern territories. This journey takes us to Central and North Arabia, the eastern Roman territories, Syria, and as far as southern Mesopotamia.

Through its unique content, this inscription enlightens the historical geography of Arabia in the 3rd century AD and provides an overview of the tribal and political map of the region at a little-known period.

Following a short presentation of the text, the nature of each of these twelve territories will be analysed and an attempt to locate them will be proposed in order to draw the political map of Arabia and the Near East as it was at the time of this text.

\section{A unique geographical testimony in the 3rd century}

Inscription Riyām 2006-17 was discovered on the site of Jabal Riyām, Sana'a governorate, Yemen (Fig. 1). 


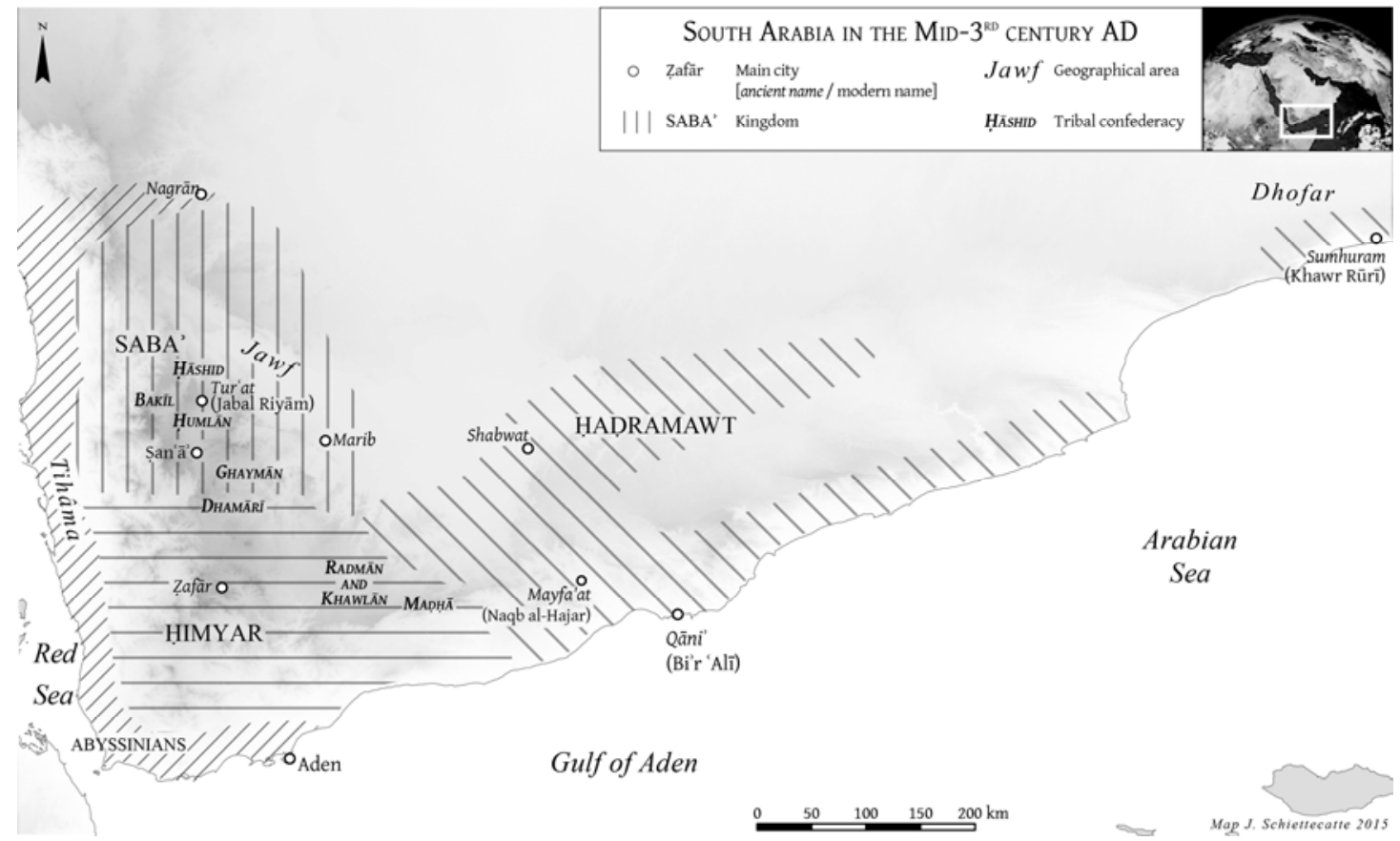

Figure 1: A political map of South Arabia in the mid-3rd century AD (C) J. Schiettecatte, 2015).

There, the ruins of an ancient temple dedicated to the god Ta'lab had been freshly looted and 26 misappropriated inscriptions from this deliberate damage were stored in the courtyard of a house in the village of Riyām. Sixteen texts have been dated to the 7th-4th centuries BC and were recently published (ARBACH \& SCHIETTECATTE 2012). A second group comprises ten other texts dated to the 1 st-3rd century $\mathrm{AD}$ according to palaeographical criteria. Inscription Riyām 2006-17 is one of these (Fig. 2). The philological analysis of this inscription and the discussion regarding its dating was recently completed by the authors (ARBACH \& SCHIETTECATTE, in press) and will not be repeated here except for a few chronological features. Inscription Riyām 2006-17 reads:

${ }^{(1)}[\ldots \ldots]^{(2)}$ dedicated (to their lord) $\left[\text { Ta'lab Riyām }{ }^{\text {um }}\right]^{(3)}$ Master of Tur' ${ }^{\text {a }}\left[\ldots \ldots{ }^{(4)}\right.$ grant them the goodwill [and the satisfaction of their $1 \mathrm{o}]^{(5)}$ rds Yarīm Yuharhi $[\mathrm{b}$ and his sons/brothers A $]^{(6)}$ wsallatt and Barig of the (li)[neage of Batac ${ }^{c}$ lords] ${ }^{(\dot{)})}$ of the palace Wakil ${ }^{\mathrm{um}}$ and $h\left[\ldots \ldots\right.$ their ${ }^{(8)}$ lord Ta'lab $[\ldots \ldots]^{(9)}$ and prosperous possessions and [good harvests] ${ }^{(10)}$ in their fields and their $\left[\ldots \ldots . . .{ }^{(11)}\right.$ plantations. And praised Hay $[\ldots]^{(12)}$ steward of Yarīm, Awsallāt, and Barig, the power and ${ }^{(13)}$ the authority of Ta'lab Riyām ${ }^{\text {um }}$, as He brought him back from ${ }^{(14)}$ the land of the North when his lords dispatched him on a (diplomatic) mission ${ }^{(15)}$ and he reached the land of $\mathbf{A s d}^{\mathbf{a}}$, the land of ${ }^{(16)}$ Nizār ${ }^{\text {um }}$, the land of Tanūkh, the land of Lihyān, ${ }^{(17)}$ the land of Tadmur $^{\text {um }}$, the land of Nabat ${ }^{\text {um }}$, the land ${ }^{(18)}$ of Rūmān, the land of Lakhm ${ }^{\text {um }}$, the land of Gha ${ }^{(19)}$ ssān, the land of Ma $\mathbf{M a d d}^{\mathbf{u m}}$, the land of Tayy ${ }^{\mathbf{u m}}$, and the ${ }^{(20)}$ land of Khașāsat $^{\text {ann }}$. And they entrusted (this inscription) to the protection of Ta'lab Riyām. ${ }^{1}$

\footnotetext{
${ }^{1}$ Transcription of Riyām 2006-17: ${ }^{(1)}\left[\ldots \ldots \ldots .{ }^{(2)}(h) q n y w\left(s^{2} y m-\right)\left[h m w \quad T^{\prime} l b R^{2} y m^{m}\right]{ }^{(3)} b^{c} l \operatorname{Tr}^{c} t(\underline{t})\left[\ldots \ldots s^{l}\right]^{(4) c} d-\right.$ $h m w h z(y)\left[w-r d w{ }^{\prime} m r^{\prime}-h\right]^{(5)} m w$ Yrm Yhrhb $\left[w-b n y-h w\left(\left({ }^{\prime} h y-h w\right)\right){ }^{\prime}\right]^{(6)} w s^{1} l t w-B r g(b)\left[n w B t^{c}{ }^{\prime} b^{c} l\right]^{(7)} b t^{n} W k l^{m} w-$

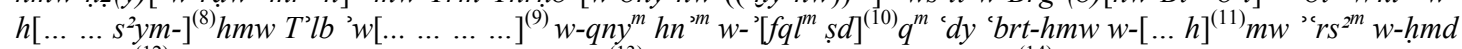
$H y\left[\begin{array}{ll}\ldots & m\end{array}\right]^{(12)} q t w y$ Yrm w-'ws llt w-Brg hyl $[w]_{-}^{(13)} m q m T^{\prime} l b$ Rym $^{m}$ hgn 'wl-hw ${ }^{(14)}$ bn 'rd $S^{2} m t$ b-kn blt-hw ' $m r^{\prime}-$

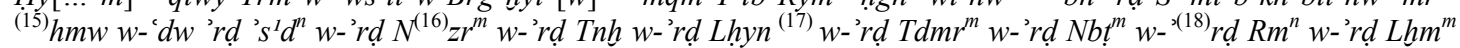

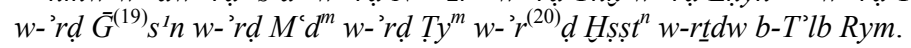




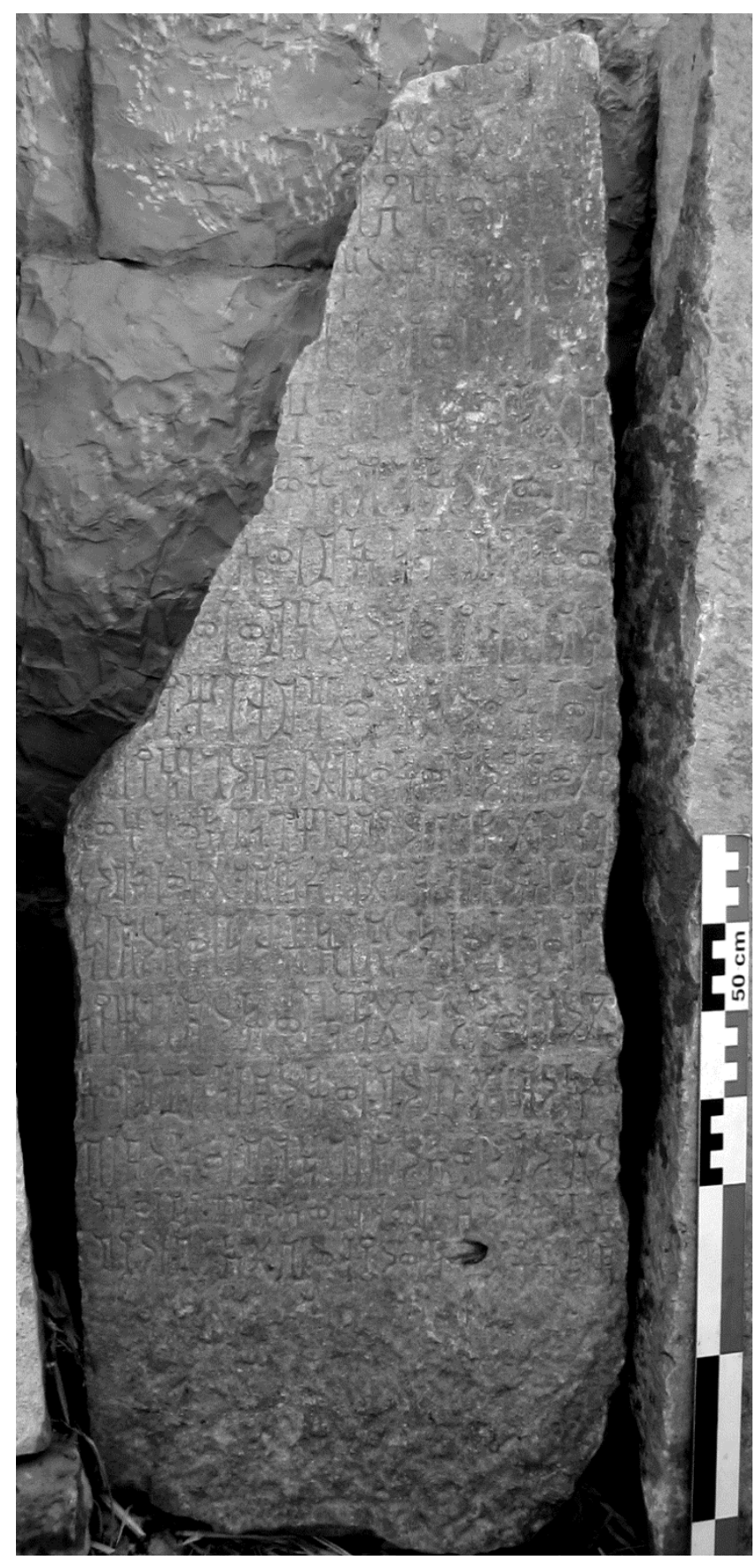

Figure 2: Inscription Jabal Riyām 2006-17 (C J. Schiettecatte, 2006).

The unknown authors of the text give thanks to Ta'lab Riyām, the main deity of the tribes of Hāshid and Humlān in his sanctuary on the Jabal Riyām, in order to gain the favour of their lords of the lineage of Bata ${ }^{c}$ as well as fruitful crops and harvests. They follow the common format of a dedication usually made to this deity.

There follows a more specific praise of one of the authors - whose name is only partly preserved (Hay $\left[\overline{\mathrm{u}}^{\mathrm{um}}\right]$ or Hay[ $\overline{\mathrm{u}}^{\mathrm{c}}$ athtar] $)$ - who has returned safely from lengthy travels in the northern territories: those of the tribes of West Arabia (Asd, Nizār, Ghassān, Khașāșat), North Arabia (Liḥyān, Nabaț, Țayyi'), Central Arabia (Ma'add), the Euphrates valley (Tanūkh), and the Near East (Lakhm, Tadmur/Palmyra, Eastern Provinces of the Roman Empire). This expedition was undertaken on behalf of his lords Yarīm Yuharhib, Awsallāt, and Barig of the 
lineage of Bata', princes of one of the main Sabaean tribe, Humlān, a faction of the tribal confederacy of $\operatorname{Sam}^{\mathbf{1}}$.

Although neither king nor calendar year is given in this inscription, several clues - the palaeography, territories listed in the inscription, and names of the lords who can be identified to princes of the lineage of Bata ' and Hamdān, leaders of the tribe of Humlān and Hāashid allow us to date inscription Riyām 2006-17 quite confidently sometime between AD 223 and 300 (ARBACH \& SCHIETTECATTE, in press). More hypothetically, it can be dated either from the beginning of this time span (c.225-235), when the rapid succession of several royal dynasties on the Sabaean throne made it possible for the lords of Bata ${ }^{c}$ and Hamdān to become emancipated and dispatch a diplomatic mission, or - more probably - at the very end of the existence of the Sabaean kingdom (c.260-280), when the lords of Bata ${ }^{c}$ and Hamdān conducted an armed resistance against the hostile kingdom of Himyar.

\section{A political map from the Euphrates to Yemen in the 3rd century $A D$}

Riyām 2006-17 mentions twelve territorial and political entities. An assessment of their political role and their relations with South Arabian kingdoms, and an examination of their location in the 3rd century make it possible to draw the outlines of a political map of the Arabian Peninsula and beyond at that time (Fig. 3).

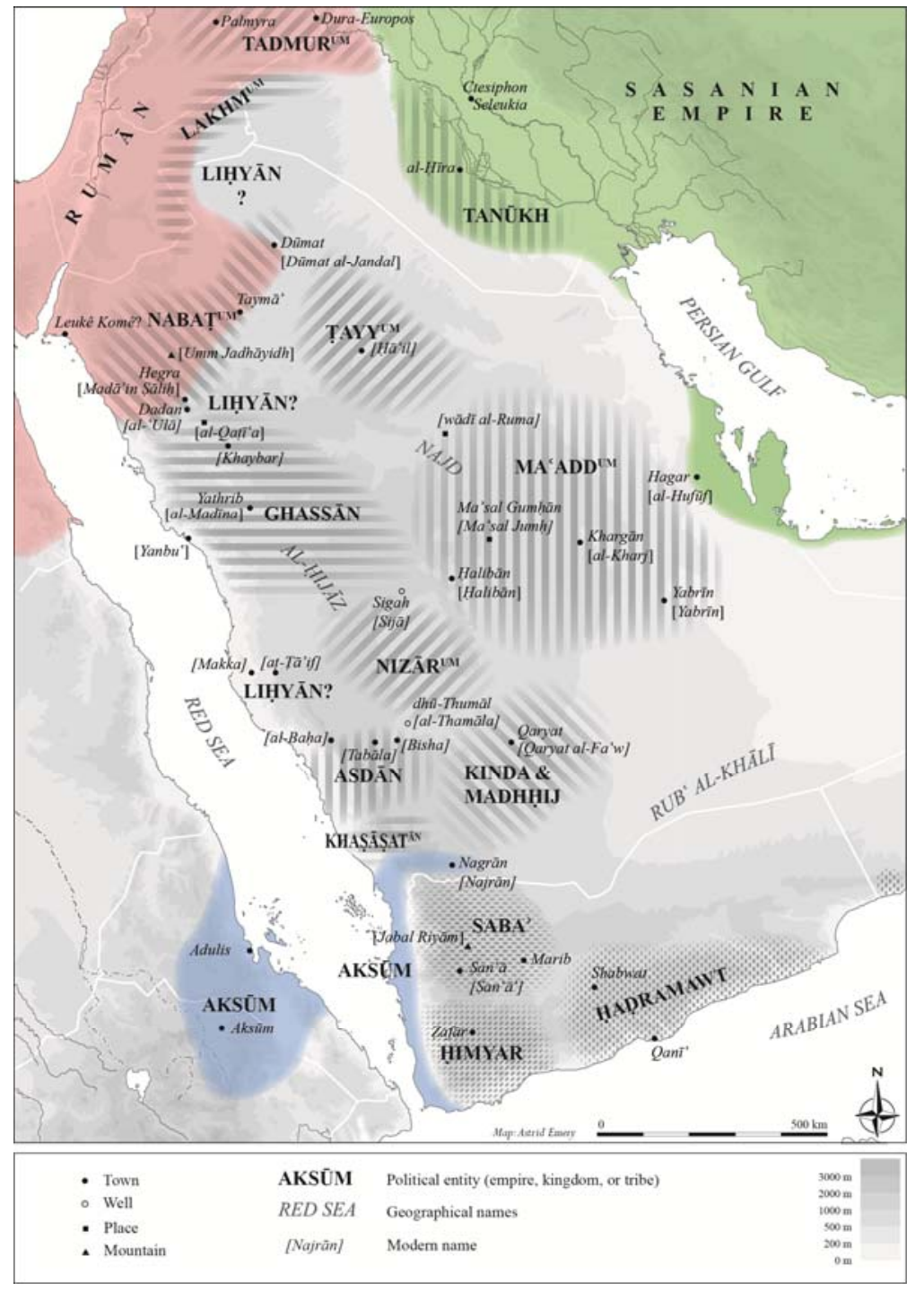

Figure 3: A political map of Arabia and the Middle East showing the tribes and kingdoms mentioned in inscription Jabal Riyām 2006-17 (C) A. Émery \& J. Schiettecatte, 2015). 


\section{In the land of the North...}

As a prelude to the list of the territories visited, an opening word indicates that the journey was carried out in the land of the North $\left({ }^{\prime} r d S^{2}{ }^{2} m t\right)$. According to the context of the inscription, the interpretation is twofold.

The first option would be to consider the 'Land of the North' as a political entity, a possible hypothesis as an unpublished inscription from the temple Awām in Ma'rib mentions the dispatching of two emissaries to 'Caesar, king of the North' in AD $311 .^{2}$ In this inscription, the North (Sha'mat) is identified as the Eastern provinces of the Roman Empire. In Riyām 2006-17 however, Romans $\left(\mathrm{Rm}^{n}\right)$ are explicitly mentioned by their name in the territories visited. We therefore consider the 'land of the North' as the wide area stretching north of South Arabia and encompassing the tribal territories and kingdoms listed later.

\section{The land of Asd}

The tribe of Asd (Sabaic: Asd ${ }^{\text {an }} /$ Asd/al-Asd; Arabic: al-Azd) is known from the early Christian era onwards from Sabaic and Hadramitic inscriptions. ${ }^{3}$ The latest Sabaic mention is inscription 'Abadān 1/16, dated to AD 360, stating that two factions of the Asd, Șudayy ${ }^{a}$ and Rasan, were defeated by the Himyarite king.

A clue to the location of the land of Asd is provided by inscription Ja 635 where mention is made of a war led by the troops of Sha' ${ }^{\text {um }}$ Awtar king of Saba' and dhū-Raydān against the king of Kinda and Qaḥtān and the inhabitants of Qaryat dhāt-Kahl (present-day Qaryat alFāw). The battle took place 'on the border of the territory of al-Asd, at the crossing-place by the two wells of dhū-Thumāl'. ${ }^{4}$ There are two candidates for this location:

1) the wells of al-Thamāla, $51 \mathrm{~km}$ north-east of Bīsha and $252 \mathrm{~km}$ west-north-west of Qaryat al-Fāw; ${ }^{5}$

2) Wādī Thumāla, $31 \mathrm{~km}$ south-east of al-Ṭāif. This is $500 \mathrm{~km}$ west-north-west of Qaryat al-Fāw, however, and it is unlikely that Sabaean troops were engaged in a fight against Kindites and inhabitants of Qaryat at such a distance from the site.

The land of Asd ${ }^{\text {än }}$ would thus have extended west of Bīsha, in the south-western heights of Saudi Arabia, straddling the regions of al-Bāha and 'Asīr. Their territory was probably comparable to that of the tribe of Azd Sarāt on the eve of Islam, stretching from Bīsha to the Tihāma shores, the southern limit being approximately al-Nimāṣ and the northern one the modern town of al-Bāha (STRENZIOK 1960: 834). It is worth noting that according to Ibn alKalbī, one of the main pre-Islamic deities of the Azd Sarāt - Dhū-l-Khalașa - had its sanctuary in Tabāla (FARIS 1952: 29; STRENZIOK 1960: 836; ROBIN 2012a: 51), c.40 km west of Bīsha and $75 \mathrm{~km}$ south-west of al-Thamāla.

\footnotetext{
${ }^{2}$ MB 2004-I-123: $Q y s^{1} r^{m} m l k S^{2} m t$. Inscription presented by M. Maraqten on several occasions: 9th Rencontres Sabéennes, Sana'a, 2004; 9ICAANE, Basel, 2014; 19th Rencontres Sabéennes, Pisa, 2015. On the latter occasion, he corrected the reading of the date he had published incorrectly (MARAQTEN 2014: 100) from 404 Himyarite era to 421 Himyarite era, i.e. AD 311.

${ }^{3}$ The earliest reference can be found in a Sabaic inscription that mentions 'an expedition in the Land of Asd' (YM 10703/4: $m t w t t^{\prime} r d{ }^{\prime}{ }^{\prime} s^{1} d$ ). This text comes from Wādī al-Shuḍayf (north of the Jawf valley, Yemen). It is dated to the 1st-2nd century AD by RoBIN \& VoGT 1997: 123.

${ }^{4}$ Inscription Ja 635/36-37: b-knf ' $r \underline{d}^{(37)}{ }^{(37} l{ }^{\prime} s^{1} d m g z t ~ m w n-h n \underline{d}-\underline{T} m l$. It comes from the temple of Awām in Ma'rib, and dates to the reign of Sha $r^{\text {um }}$ Awtar (c.215-225).

${ }^{5}$ This location was proposed by Wissmann who identified the place with Tomala mentioned by Pliny (Nat. Hist., VI, 28, 154): WisSMANN 1964: 184; WisSMANN \& MÜlLER 1977: 38. See also AL-SHeIBA 1987: 21. For SPRENGER

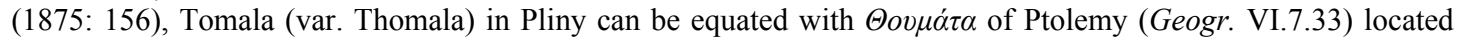
halfway between the Jawf valley (Yemen) and Mecca.
} 
In the 3rd century $\mathrm{AD}$, the tribe of Asd appeared as an autonomous kingdom ruled by a king (malik), and played a significant role in the South Arabian political landscape.

The rock of al-'Uqla, near Shabwa, the place of investiture of the kings of Hadramawt in the 3rd century $\mathrm{AD}$, is engraved with three inscriptions mentioning the presence of Asdites sojourning in the region. ${ }^{6}$ Among these, Ja 957 is of particular interest since the author,

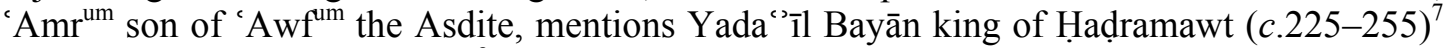
as his 'son-in-law' or 'ally'. An alliance by marriage between Yada' 1 1̀ Bayān and a noblewoman of Asd, daughter of 'Amr" son of 'Awf ${ }^{\text {um }}$, makes sense if we follow the translation proposed by Pirenne of a later inscription from al-'Uqla which reads 'Rabbīshams

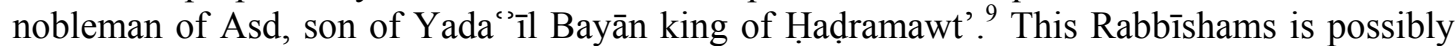
one of the two last kings of Hadramawt (c. AD 300). ${ }^{10}$ The close proximity between the Arab tribe of Asd and the Hadrami power is obvious.

Regarding the connections with Saba', Ilīsharah Yahḍub king of Saba' (c.235-255) sent an embassy 'to the kings of the tribes Ghassān, al-Asd, Nizār" and Madhhig ${ }^{\text {um }}{ }^{\text {, }}{ }^{11}$ a few years later, the same Ilīsharah Yaḥ̣ub and his brother Ya'zil Bayān dispatched a 'mission to the kings of the north, al-Hiarith son of Ka ${ }^{\mathrm{c}} \mathrm{b}^{\mathrm{um}}$ king of Asd, and Mālik ${ }^{\mathrm{um}}$ son of Baddā' king of Kinda and Madhhigim and some (other) Arabs'. ${ }^{12}$ In the early 4th century, another embassy was sent by the Himyarite king Shammar Yuhar ish to Mālik ${ }^{\text {um }}$ son of Ka $\mathrm{a}^{\mathrm{um}}$ king of Asd. ${ }^{13}$ Two kings of Asd are thus known by name: al-Hāarith son of $\mathrm{Ka}^{\mathrm{c}} \mathrm{b}^{\mathrm{um}}$ and Mālik ${ }^{\mathrm{um}}$ son of $\mathrm{Ka}^{\mathrm{c}} \mathrm{b}^{\mathrm{um}}$. It is unlikely they were siblings as between 50 and 70 years separates one inscription from the other. ${ }^{14}$

Throughout the 3rd century, the tribe of Asd fostered a friendship with the Sabaean kingdom and its ally, the kingdom of Hadramawt. ${ }^{15}$ This close proximity between Asd, Saba', and Hadramawt did not last after the annexation of the two latter kingdoms by Himyar. If Shammar Yuhar'ish sent a successful embassy to the king of Asd two generations later, the

${ }^{6}$ Ja $938+939 / 3$ and Ja 962/2: nisba 's ${ }^{1} d y^{n}$; Ja 957/1-2: nisba 's ${ }^{I} d y^{h n}$.

${ }^{7}$ On the date of Yada' ${ }^{(3} 1$ Bayān king of Hadidramawt and his place in the royal succession, see ANTONINI \& ROBIN 2015: 9

${ }^{8}$ Sabaic hth. See JAMME 1962: 56.

${ }^{9}$ Ja 997/1-3: $R b s^{2} m s^{1}$ hyr ' $s^{1} d^{n}$ bn Y Y's l Byn mlk Hdrmt. The translation is adapted from Pirenne (1990: 120). This genealogical reconstruction rules out the translation proposed by A. Jamme (1963: 59-60): "Rabbīshams, superintendent of the soldiers, son of Yada' 'īl Bayān, king of Ḥaḍramawt".

${ }^{10} \mathrm{He}$ is mentioned as a co-regent of Sharah'îl in a text dated to the reign of Shammar Yuhar ish king of Saba', dhū-Raydān, Haḍramawt and Yamanat (Ja 656/11-12: $S^{2} r h^{(12)} l w-R b s^{2} m s^{l^{m}} m l k y$ Hdrmwt). Since Shammar Yuhar ish bears the long title of the king of Himyar, this text can be dated sometime between 300 and 312 . This identification is also defended by Frantsouzoff (2015: 238, 246).

${ }^{11}$ ZI 75: $b$ - ' $b r{ }^{\prime} m l k$ ' ${ }^{2}{ }^{c} b^{n} \bar{G} s^{l} n w-l-{ }^{\prime} s^{1} d w-N z r^{m} w-M d \underline{d} g^{m}$.

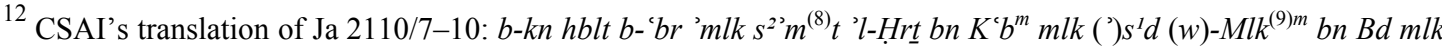
$K d t w-M \underline{d} \underline{\underline{b}} g^{m} w-\underline{d}-b n^{(10)}{ }^{\prime} r b^{n}$.

${ }^{13}$ Sharaf 31/9-10: $b$ - ${ }^{\circ} b r M l k^{m} b n K^{(10)}\left[{ }^{c} b\right]^{m} m l k-l-{ }^{\prime} s^{1} d$.

${ }^{14}$ Ibn al-Kalbī’s genealogy mentions Mālik b. Ka‘b b. al-Hārith b. Ka b b. ‘Abdallah b. Mālik b. Nașr b. al-Azd (CASKEL 1966, I: table 210). Here, Mālik b. Ka'b is a grandson of al-Hārith b. Ka'b. If it were chronologically coherent, drawing a parallel between the 3rd-4th-century testimonies and al-Kalbī's genealogy is of course dubious.

${ }^{15}$ Yada' 1 1l Bayān king of Haḍramawt son of Rabbīshams, of the freemen of Yuhab'ir, acceded to the throne of Hadramawt after the overthrow of Ilī'azz Yalut king of Hadramawt by the Sabaean king Sha' ${ }^{\mathrm{um}}$ Awtar (c. AD 225). Yada' 'îl Bayān's accession could hardly have taken place without the support of the Sabaeans. 
Himyarites and the Yaz'anides led an expedition against the tribal factions of Asd in AD 360 ('Abadān 1/16).

To sum up, the tribe of Asd appears to be:

- a political entity headed by a king at least in the mid-3rd-early 4th century AD and controlling the territory west of Bīsha, today in the south-western heights of Saudi Arabia straddling the regions of al-Bāḥa and 'Asīr;

- a long-standing ally of the Sabaeans, receiving their diplomatic missions and allowing the Sabaean army to cross their territories when they faced the kingdom of Kinda;

- a faithful ally of the Hadramawt, after the Sabaean king Sha ${ }^{\text {c }}{ }^{\text {um }}$ Awtar, of the lineage of Hamdān, dismissed Ilì'azz Yaluṭ king of Haḍramawt (c. AD 225) and promoted the accession to the throne of Yada' $\overline{1}$ l Bayān son of Rabbisshams, of the freemen of Yuhab'ir. A noblewoman of Asd would have been given to him in marriage. A child from this marriage would have kept the title of noble of Asd and possibly ascended the throne of Hadramawt, just before the kingdom was annexed.

\section{The land of Nizār}

In Arabic tradition Nizār ${ }^{\text {um }}$ in Sabaic is identified as the tribe of Nizār. In Ibn al-Kalb̄̄'s genealogy, Nizār b. Ma'add b. 'Adnān is the common ancestor of most of the Arab tribes of the North (CASKEL 1966, I: table 1; 1966, II: 448; LEVI DELLA VIDA 1995).

If the historical existence of this tribe has been previously denied, ${ }^{16}$ several pre-Islamic inscriptions have proved otherwise. The tribe of Nizār is mentioned in three Sabaic inscriptions from the mid-3rd to the mid-4th century AD (Riyām 2006-17, ZI 75, and 'Abadān 1) and in the funerary inscription of Mara'-1-Qays at al-Namāra, southern Syria dated AD 328.

The location of its territory is based on very little evidence. In the Old Arabic inscription of al-Namāra, King Mara'-1-Qays is said to have ruled 'the two Syrias', Nizār and Ma'add (see below). Kropp insisted that these tribal names are those of the eponyms of Arab tribes of the North (KROPP 1990: 77), that is, in northern and Central Arabia. A much more significant element is given in the Sabaic inscription 'Abadān 1 (AD 360):

'Barīl ${ }^{\mathrm{um}}$ son of $[\mathrm{Ma}]^{c}[\mathrm{~d} \overline{\mathrm{i} k a r i}] \mathrm{b}$ participated in combat for the first time $[\ldots \ldots]$

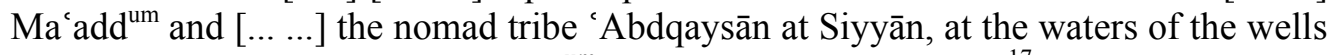
of Sigah, between the Land of Nizār ${ }^{\text {um }}$ and the Land of Ghassān'. ${ }^{17}$

According to this text, the wells of Sigah at Siyyān mark the border of the land of Nizār, at least in the mid-4th century. Robin recognized in these place names the wells of Sija an the steppe area of al-Siyy, located in Central Arabia, c.330 km east-south-east of Medina and $380 \mathrm{~km}$ north-east of Mecca. ${ }^{18}$

\footnotetext{
${ }^{16}$ LEVI Della VIDA 1995: 84-85: 'the term Nizār corresponds to a political ideal rather than to a historical reality (...) it is evident that we cannot speak of Nizār as a tribe which had a real historical existence'.

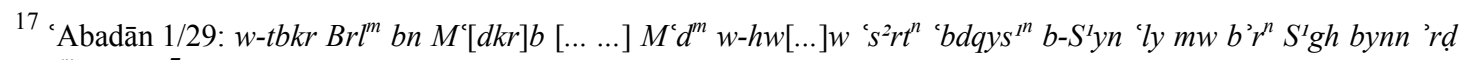
$N z r^{m} w{ }^{\prime} r d \bar{G} s^{I} n$. Translation by RoBIN \& GAJDA (1994: 119) in the English version proposed by the CSAI.

${ }^{18}$ RoBIN 1986: 183. Thilo (1958: 89) describes Sijā as 'Brunnen, nahe dem Ursprung eines der beiden Quellarme des W. Ğarīb/Ğerīr, südl. vom heutigen Mešāf Siğā'; and al-Siyy as a 'Steppe östlich vom südl. 'Aqīq, etwa der südwestliche Teil von Wağra' (ibid.: 92).
} 
Inscriptions mentioning Nizār in the 3rd-4th century AD mirror the political role it played at that time. It was then one of the four main tribes in the area stretching from Najrān to Yathrib (present-day Medina), headed by a leader who was given the title of king ( $m l k$ ) by the Sabaean authority. This is illustrated by a diplomatic mission sent by Ilīsharah Yahḍub king of Saba' and dhū-Raydān (c.235-255) 'to the kings of the tribes Ghassān, al-Asd, Nizār ${ }^{\text {um }}$ and Madhhig ${ }^{\text {um }},{ }^{19}$

Eighty years later, c. AD 328, the king Mara'-1-Qays son of 'Amr, ${ }^{20}$ in his epitaph from alNamāra, bore the title of 'king of all 'Arab who bound on the crown ${ }^{21}$ and ruled the two Syrias and Nizārū and their kings' ${ }^{22}$ The leader and the tribe of Nizār had then been subjugated to a king who ruled over an area stretching from Mesopotamia to northern and Central Arabia.

In AD 360, Nizār simply appears as a territory ${ }^{23}$ the border of which is the setting of a confrontation between the tribe of 'Abdqaysān and the coalition of Himyar, Kinda, Madhhig, and Murād, during Himyar's military campaign against Ma'add. At that time, Nizār could still have been part of the entity named Ma'add. Subsequently, Nizār is no longer mentioned and one wonders whether the tribe might have been finally incorporated within Ma'add; it would explain the filiation between Nizār and Ma'add in the genealogy of Ibn al-Kalbī, as a memory of a forgotten past.

To sum up, the tribe of Nizār appears to be:

- a political entity headed by a ruler who is endowed with the title of king $(\mathrm{mlk})$ by the Sabaean king at least in the 3rd and first half of the 4th century AD;

- a tribe spreading in the steppe, somewhere east of Mecca;

- a tribe subjugated to the rule of king Mara'-1-Qays who took control of a wide territory stretching from Mesopotamia to Central Arabia for an undetermined length of time.

\section{The land of Tanükh}

Tanūkh can be easily identified as the tribe attested in the early centuries of Islam in Lower Mesopotamia and the upper Euphrates (CASKEL 1966, II: 544-545; SHAHID 2002). The tribe is also known in pre-Islamic sources from the 3rd century onwards.

Some scholars agree with the identification of the Thanouitai of Ptolemy (Geogr. VI.7.23) with Tanūkh (SPRENGer 1875: 208; WiSSMANN 1964: 192-193). Ptolemy does not locate this ethnic group precisely; having listed tribes from North and Central Arabia, he just mentions that going to the south, one finds the Katanitai (Qaḥtạn) and then the Thanoutitai.

\footnotetext{
${ }^{19}$ ZI 75: $b-{ }^{c} b r^{\prime} m l k{ }^{\prime} s^{2} b^{n} \bar{G} s^{1} n w-l-{ }^{\prime} s^{l} d w-N z r^{m} w-M d \underline{d} g^{m}$.

${ }^{20}$ Possibly the son of 'Amr b. 'Adī, king of Lakhm in al-Hīra (RoBIN 2008: 182).

${ }^{21}$ Louvre 205 = AO 4083/1: Mr'lqys br 'mrw mlk' $l-{ }^{\prime} r b k l-h d \underline{d}$ ' $s r$ 'l-tg. The translation is Macdonald's (FIEMA et al. 2015: 405), "Arab' referring to an area in Mesopotamia. It is adapted from the alternative translation proposed by M. ZWETTLER (1993): 'king of the entire territory of al-'Arab'.

${ }^{22}$ Louvre 205 = AO 4083/2-4: w-mlk 'l-'sdyn/'sryn $w$-Nzrw $w-m l w k-h m$ (...) $w$-mlk $M^{c} d w$. Translation by Macdonald (FIEMA et al. 2015: 405). Regarding the reading of ' $l$-'sryn or ' $l$-'sdyn, it is uncertain since the same letter can be used for both R and D (KROPP 1990: 76). Kropp reads 'l-'sdyn and translates it 'the two tribes of Asad' (i.e. Asd Shanū'a and Asd 'Umān). This hypothesis is highly unlikely for Robin, who sticks to the transcription 'l-'sryn and suggests 'the two Syrias' (AvNER et al. 2013: 250, n. 32). This translation is also favoured by Macdonald (FIEMA et al. 2015: 405).
}

23 'Abadān 1/29: 'r $r$ d $N z r^{m}$. 
Qahțān being the tribe that settled in Qaryat al-Fāw, it would thus indicate a territory somewhere in the south of Saudi Arabia, which is in contradiction with later data. The identification of the Thanouitai as Tanūkh remains questionable unless we give credence to historical traditions that speak of a migration of Tanūkh from Tihāma to the Gulf shores (SHAHID 2002: 206).

Later, inscription LPNab 41 found at Umm al-Jimāl, south of Bușrā (Syria) mentions 'Gadhīmat king of Tanūkh'. ${ }^{24}$ Whether at that time the territory of Tanūkh stretched across the Syrian Desert up to Umm al-Jimāl, south of Bușrā, cannot be ascertained as the reasons for the presence of the funerary stela of the tutor of this king of Tanūkh at that location remain unclear. A date in the mid-3rd century has been proposed for this inscription, based on questionable arguments. ${ }^{25}$ Thus, if this inscription reports the existence of a king of Tanūkh, neither his date nor the extent of his kingdom can be inferred.

Be that is it may, it is highly likely that the tribe of Tanūkh was settled in Lower Mesopotamia by the late 3rd-early 4th century, most probably in the region of al-Hiira on the right bank of the Euphrates, where it is well attested in late antiquity. This location would be consistent with the Sabaic inscription Sharaf 31 (c. AD 300-312), in which an envoy of the Hiimyarite king 'reached Qațūșif (Ctesiphon) and Kūk (Seleukia), the two Persian royal cities, and went to the land of Tanūkh'. ${ }^{26}$

From the mid-5th century onwards, the tribe of Tanūkh and its king were the target of at least two Himyarite expeditions attempting to subjugate the Najd and north-east Arabia. ${ }^{27}$

In the 6th century AD, Tanūkh was still one of the most influential tribes of al-Hīra, together with the tribes of al-' Ibād and al-Aḥlāf (TTABARī/NÖLDEKE 1973: 24; SHAHID 2002: 206).

To sum up:

— it was a political entity headed by a king, possibly in the 3rd century and certainly in the 5th century;

- Tanūkh appears as a tribe that had settled in southern Mesopotamia at the latest at the end of the 3rd century AD. Al-Hîra remained the central location of the tribe until the advent of Islam.

\section{The land of Lihyān}

The tribe of Lihyān is attested in many Dadanitic inscriptions, ${ }^{28}$ in the expression 'king of Lihyān', at the earliest in the mid-6th century BC and until at least the mid-4th century BC

\footnotetext{
${ }^{24}$ The inscription reads 'This is the memorial of Fihr son of Sullay, tutor of Gadhīmat king of Tanūkh' (LPNab 41:

${ }^{(1)} d n h n p \check{s} w$ Fhrw ${ }^{(2)} b r \breve{S l} l y r b w$ Gdymt ${ }^{(3)}$ mlk Tnh $)$. Translation: MACDONALD 2015: 28-30.

${ }^{25}$ RoBIN (2008: 181) made the assumption that Gadhīmat king of Tanūkh mentioned in inscription LPNab 41 at Umm al-Jimāl is the king of al-Hīra, Jadhīma al-Abrash, mentioned in Arab tradition; the dating of his reign to the mid-3rd century rests on the association of Queen al-Zabbā' with Jadhīma al-Abrash in Arab tradition and the identification of this queen with Zenobia of Palmyra. Macdonald has called this hypothesis into question (MACDONALD 2015: 30).

${ }^{26}$ Sharaf 31/11-12: $w-w z^{\prime} m z^{\prime}$ ' $d y$ Qtws $f w$-Kwk $m^{(12)} m l k t y ~ F r s^{1} w$-'rḍ Thh. After Müller’s translation (MÜLLER WW 1974: 157).

${ }^{27}$ The first is mentioned in the Sabaic inscription al-'Irāfa 1, c. AD 445 (GAJDA 2004; re-edited by RoBIN 2008: 200f.). The second is mentioned in the Sabaic inscription Ma’sal 3, c. AD 473 (Wādī Ma’sal, Central Arabia). The text reports the defeat of a king of Tanūkh.

${ }^{28}$ FARÈS-DRAPEAU 2005. This corpus has been labelled 'Dedanite', 'Lihyanite', or 'Dédano-Lihyanite'. Nevertheless, it seems more appropriate to qualify these texts as Dadanitic (MACDONALD 2000: 33), according to the place they mainly come from (Dadan, present-day oasis of al-'Ulā), rather than after the specific kingdoms of Dadan or Liḥyān.
} 
(ROHMER \& CHARLOUX 2015: 300). Lihyān was then a kingdom occupying the area of modern al-'Ulā.

Outside the oasis of al-'Ulā, south-west of Taymā', four additional inscriptions in a local derivative of Imperial Aramaic were left by a certain Mas'udū king of Lihyānn ${ }^{29}$ and 'Shahrū king of Lihyānn, ${ }^{30}$ The kingship of Mas 'udū and Shahrū is questionable. ${ }^{31}$

In South Arabia, the tribe of Lihyān is mentioned in a Sabaic inscription, B-L Nashq, from alBayda $\vec{a}^{3}$ in the Jawf valley (Yemen), and probably dating back to the very early 6 th century BC. ${ }^{32}$ Its author undertook a commercial expedition in Gaza and Cyprus, and a mission for his king 'in the land of Dhakar ${ }^{\text {um }}$, Lihyān, Ab $\overrightarrow{i ̀}^{\prime}$ ôs and Hanak'. ${ }^{33}$ The name later appears on the Minaic stela from Ma ${ }^{\top} \bar{n} n$ in the Jawf valley (Yemen), where Minaean merchants listed their matrimonial alliances with women from cities or kingdoms located along the caravan trail. One of them married ' $M s^{l} q y$, free woman of Lihyān' ${ }^{34}$ This text is ascribed to the 5 th-mid4th century BC according to the place names mentioned (LEMAIRE 1996: 39-44).

Around the 3rd-2nd century BC, the Lihyanites were outdone by competitive tribal groups. ${ }^{35}$ There is no further mention of them before the time of the Prophet Muhammad, except by Pliny (Nat. Hist. VI.32.13: Lechieni), who is no doubt referring to an earlier source, ${ }^{36}$ and in four undated Safaitic inscriptions from Syria and Jordan (see below). It is thus unexpected to find a mention of a land of Lihyyān in Riyām 2006-17.

Regarding the location of this territory, Lihyān was established in the area of al-'Ulā (northern Hijāz) and its immediate surroundings at least until the 3rd century BC (ROHMER \& CHARLOUX 2015). Subsequently, its location remains conjectural. Three hypotheses can be put forward.

Firstly, the region of al-'Ulā: although the kingdom of Lihyān was brought to an end five or six centuries earlier than inscription Riyām 2006-17, a people who considered themselves to be Lihyanites might still have been living in the surrounding area of al-'Ulā and their land continued to be called by its former name. In this case, in Riyām 2006-17, Lihyyān was not the setting of a diplomatic meeting but a territory that was passed through, squeezed between Ghassān and Nabaṭ.

Secondly, somewhere between al- 'Ulā and Mecca: a tribe of Lihyān, a branch of Hudhayl (CASKEL 1966, I: table 58), settled north-east of Mecca on the eve of Islam (LEVI DELLA VIDA 1986: 769). The banū Lihyān were then custodians of the idol of Hudhayl at a place called Ruhăt, the location of which is thought to be either in the environs of Yanbu' (Red Sea coast west of Medina), or more probably close to Mecca (RENTZ 1971: 559-560). The banū

\footnotetext{
${ }^{29}$ At al-Khabū al-gharbī: JSNab 334 and 335; at al-Khabū al-sharqī: JSNab 337.

${ }^{30}$ At Sarmadā’': AL-THEeB 2014: 34-35.

${ }^{31}$ Rohmer \& ChArloux 2015: 302: 'Mas'ūdū and Shahrū are self-proclaimed kings with doubtful ties to the historical core of the Lihyanite kingdom. Even if we take their claim to kingship seriously, we have to bear in mind that the title of king often refers to tribal shaykhs in first-millennium BC Arabia'.
}

${ }^{32}$ BRON \& LEMAIRE (2009: 19-29) assumed that the mention of a war between Chaldea and Ionia might refer to events that happened c. 600 or $557 \mathrm{BC}$.

${ }^{33}$ B-L Nashq/18-19: 'd 'rḍ D $k r^{m} w-L^{(19)} h y n w-' b$ 's $s^{I} w-H n k$.

${ }^{34} \mathrm{Ma}^{\mathrm{i} i ̄ n}$ 93B/46-47: $M s^{1} q y$ hrt $L^{(47)} h y n$.

${ }^{35}$ If it has been generally believed that the Nabataeans played a significant role in Lihyān's collapse, an alternative hypothesis has been voiced recently by ROHMER \& CHARLOUX (2015: 313), according to whom the emergence of the tribe of Thamūd in the region of Hegra (Madā’in Șāliḥ) and Dadān (al- 'Ulā) might have followed the collapse of the Lihyanite kingdom and preceded the settling of the Nabataeans.

${ }^{36}$ See CASKEL 1954: 39; FARÈS-DRAPPEAU 2005: 53-54. 
Lihyān were still established in the neighbourhood of the Holy City in the 19th century, in Haddā' and Bahra, halfway between Jeddah and Mecca (RENTZ 1971: 559-560; ABU ALHASAN 2010: 272). Consequently, at the time of Riyām 2006-17, assuming that the tribe of Lihyān mentioned in Arab tradition is not just a namesake but represents the descendants of the pre-Christian Lihyanites, the land of Lihyān may have been located further south, somewhere between al-'Ulā and Mecca.

Thirdly, in the desert fringes of northern Arabia/southern Syria: two Safaitic inscriptions from Wādī Shām (southern Syria), dated between the 1 st century BC and the 4th century AD, ${ }^{37}$ relate an incursion of Lihyanites in the area (MACDONALD et al. 1996: 458-464). At the same time, three texts which have been discovered in north-eastern $\operatorname{Jordan}^{38}$ can be read in two different ways: 'the year ' $b d r b$ confronted the lineage group of Lihyān' or 'the year ' $b d r b$ 'l confronted Lihyaān', Lihyān in this case being the name of a person (M. Macdonald, pers. com.). The two inscriptions from Wādī Shām and possibly the three from Jordan could be interpreted as evidence of Lihyanite incursions, perhaps even a relocation of groups stemming from the tribe of Lihyaann on the desert margins of southern Syria, north-eastern Jordan, and northern Arabia in the early Christian era. This scenario would be consistent with the hypothesis that the author of Riyām 2006-17 listed the territories he visited in chronological order. Liḥyān would then be located near Tanūkh, Tadmur (Palmyra), and Nabaț. In this case, the land of Lihyān would overlap that of Lakhm (see below). Such a hypothesis, however, remains flimsy considering the scanty evidence to back it up.

To sum up:

- Lihyān was a political entity headed by a king at least from the 6th to the 4th century BC, perhaps later, and established in the oasis of al- 'Ulā in northern Hijāz;

- it was a tribe which might have existed in the early Christian era in the same area or which might have moved from northern Hijāz, either to the neighbourhood of Mecca or to a region straddling southern Syria, northern Arabia, and north-eastern Jordan.

\section{The land of Tadmur (Palmyra)}

Tadmur is the ancient name for the city of Palmyra, still used in modern Arabic. Acting as a buffer zone between the Roman and Parthian empires, the city rose to economic and military prominence from the 1st century BC to the 3rd century AD (EDWELL 2008: 31-62). This growth was driven by the caravan trade between Lower Mesopotamia and the Roman province of Syria. The bulk of caravan inscriptions is ascribed to the reigns of Hadrian and Antoninus, and more particularly from AD 131 to 161, a period considered by many as the most flourishing one for the city (GAWLIKOWSKI 1996; SARTRE 2001: 844-845; GOREA 2012: 471). At that time, the Palmyrene territory reached the Euphrates valley to the northeast, stretched to modern 'Ānah (Irak) to the east, to a location somewhere between Homs and Palmyra to the west, and the Syrian desert to the south (EDWELL 2008: 52; GOREA 2012: 465). Admittedly slowed down after Lucius Verus' wars, during Septimius Severus' Parthian wars, or during Ardashir and Shāpur's campaigns against Rome, the Palmyrene trade remained active until Diocletian promoted Nisibis as the only authorized point of commercial exchange between the Roman and Sasanian empires, in AD 297/8 (GOREA 2012: 475). Under the rule of Odeinath (AD 263-267) and that of his widow Zenobia with his son Wahballat (267-272), the Palmyrene territory went through an unprecedented expansion towards Mesopotamia, Anatolia, and Egypt. The emancipation of Zenobia from Roman authority was followed by the repression of Emperor Aurelian and the sack of the city. If the proposed

\footnotetext{
${ }^{37}$ On the dating of Safaitic script, see MACDONALD 2000: 45.

${ }^{38}$ KRS 2287, 2327, 2342 (KING 1990: 61-62).
} 
dating of Riyām 2006-17 is correct, the Sabaean diplomatic mission might have taken place during one of these reigns, at a time when Palmyra had reached its greatest expansion.

Echoing the growing importance of Tadmur in the early Christian era and its prominent role in long-distance trade, four documents — besides Riyām 2006-17 — show commercial and diplomatic connections between South Arabia and Palmyra in the 1st and 3rd centuries AD.

In the port of Qanī' (present-day Bi'r 'Alī) was a Dressel 2-4 amphora bearing a Palmyrene graffiti (SEDOV 2010: 187, fig. 83). Its written form has been ascribed to the first half of the 1st century AD (BRIQUEL-CHATONNET 2010: 387) and the context of the discovery dates back to the late 1st century AD (SEDOV 2010).

Two Hadramitic inscriptions from the 3rd century are dedications left by Palmyreneans who defined themselves as 'Tadhmurites' staying in the Hadrami capital Shabwa, c. AD 220, and who are to be seen either as traders or ambassadors (ROBIN 2012b: 491-492). ${ }^{39}$

The last document is the wooden Palmyrene tablet 'De Geest' found in Hoq cave, Socotra Island, and dated AD 258 (ROBIN \& GOREA 2002; GOREA 2012: 447-457). It is not possible to confirm whether its author was a sailor, trader, or emissary.

With regard to Riyām 2006-17, this is the first evidence of contacts between Sabaeans and Palmyreneans; up to now, sources only mentioned contacts between Palmyra and the South Arabian kingdom of Hadiramawt, most probably by sea. The author of Riyām 2006-17 reached Palmyra by land; it constituted the northern limit of his expedition.

To sum up:

- Palmyra was an autonomous city under Roman influence during the 1st-2nd century $\mathrm{AD}$ and a trading power with control over part of the Euphrates valley. It became integrated within the Roman province of Syria as a colony in the 3rd century AD. Its short emancipation in the reign of Zenobia and Wahballat was followed by the Roman sack of the city and its rapid decline;

— its territory spread from the Euphrates to the north-east, present-day Haditha lake (Irak) to the east, a location somewhere between Homs and Palmyra to the west, and the Syrian Desert to the south. In 270, it temporarily expanded towards Anatolia and Egypt;

— it sustained commercial and diplomatic links with South Arabian kingdoms, more specifically Ḥạ̣ramawt.

\section{The land of Nabat}

The land of Nabat ${ }^{\mathrm{um}}$ refers to the Nabataean area. Before it was taken over by the Roman Empire in AD 106, the Nabataean kingdom stretched to Bușrā (southern Syria) to the north, to Hegra (modern Madā'in Șālih) to the south, and reached the Sinai Peninsula to the west and the oases of Taymā' and Dūmat al-Jandal to the east. The area named land of Nabat in the inscription Riyām 2006-17 might be the whole region or only a part of it, but the text is not sufficiently accurate for us to be more specific.

Since the land of the Romans is mentioned later, we might be surprised at the mention of the land of Nabat a century and a half after its annexation by the Romans, but this peculiarity may

\footnotetext{
${ }^{39}$ The first text comes from Shabwa, the capital city of Hadramawt, and mentions the nisba 'the two Tadhmurites' (RES 4691/1: Támryhn); the second is a rock inscription found in the open-air sanctuary of al-'Uqla, near Shabwa; it mentions the same nisba with a different spelling (Ja 931/1-2: Tdimryyhn).
} 
be explained. During the 2nd century, there is much evidence of the Roman presence as far as the southern end of the former Nabataean kingdom: in Hegra, inscription JSNab 159 is dated to the twentieth year of the Eparchy (AD 125/126); many Latin and Greek inscriptions have been unearthed on the south-eastern gate (VILLENEUVE 2014: 37-42); a detachment of the III Cyrenaica legion was stationed there in $c$. AD 175-177 and it is assumed there was a garrison for a Roman detachment (ala Getulorum) near the Jabal Ithlib (NEHMÉ 2009: 44-48). After the early 3rd century AD, however, no Roman presence is attested in Hegra (VILLENEUVE 2014). Therefore, a first hypothesis proposes that the Sabaean envoy of Riyām 2006-17 crossed a region that was under a Roman administration which left no trace, and which was inhabited by people who went on using the Nabataean script and were recognized as belonging to a group still identified as 'Nabataean'. ${ }^{40}$ The memory of the Nabataean kingdom was vivid enough to cause the envoy to call this land by its former name, although reflecting an ethnonym rather than a political power. A second hypothesis proposes that at the time of Riyām 2006-17, the crisis happening in the Eastern provinces - and characterized among other things by the rise of a short-lived Palmyrenaean empire - made the Roman Empire relax the control of its southern margins. In this case, the land of Nabat might have been a territory with its own local authorities.

The Nabataeans and Sabaeans, both involved in the long-distance caravan trade, had been in contact during at least three centuries, but evidence is scanty. The oldest mention comes from Strabo (Geogr. XVI.4.23-24): the army of Ælius Gallus that came from Egypt and headed towards South Arabia in 26/25 BC consisted of '10,000 infantry of Romans in Ægypt, as also of Roman allies, among whom were five hundred Jews and one thousand Nabataeans under Syllaeus'. The Nabataeans joined the Romans in their military expedition against the South Arabian kingdoms as their allies, but also probably to gain ascendency over their competitors in the caravan trade, as Strabo suspects that Syllaeus, ministry of king Obodas III, guided the expedition through Arabia in such a way that he could 'spy out the country and, along with the Romans, destroy some of its cities and tribes, and then establish himself lord of all, after the Romans were wiped out by hunger and fatigue and diseases and any other evils which he had treacherously contrived for them.'

Echoing the Roman expedition, two undated Sabaic rock inscriptions, $\mathrm{Ph} 103$ and $\mathrm{Ph} \mathrm{135a,}$ were found in the valley of Najrān (PHILBY \& TRITTON 1944: 123, 127; RYCKMANS 1947: 150, 152; BEESTON 1954: 311-313; JAMME 1956: 165-171). They describe a confrontation between South Arabians and Nabataeans (Ph 103) and the defeat of the Nabataeans ( $\mathrm{Ph} \mathrm{135a)}$ (Müller's reading in MACDONALD 1994: n. 30). This episode cannot be compared to any historical event known so far. Admittedly a Nabataean contingent took part in the assault on Najrān by Gallus' expedition, but according to Strabo, Najrān was promptly seized by the army. This contradicts the defeat reported in Ph 135a.

\footnotetext{
${ }^{40}$ At least one inscription dating after the Roman annexation refers to someone who identified himself as 'Nabataean'; the author of this Palmyrene inscription, dated AD 132, describes himself as 'the Nabataean, the Rawāhaean' (CIS ii, 3973: nbty' rwhy'). Several Safaitic inscriptions mention Nabataeans but there is no way of knowing whether they predate or postdate the annexation (e.g. CSNS 661 in CLARK 1979; see also MACDONALD et al. 1996: 444ff.).

Incidentally, in the 4th century, Ammianus Marcellinus mentions the Nabataeans (Nabatheei) (Roman Hist. XIV.8.13): "Adjacent to this region is Arabia, which on one side adjoins the country of the Nabataei, a land producing a rich variety of wares and studded with strong castles and fortresses, which the watchful care of the early inhabitants reared in suitable and readily defended defiles, to check the inroads of neighbouring tribes. This region also has, in addition to some towns, great cities, Bostra, Gerasa and Philadelphia, all strongly defended by mighty walls. It was given the name of a province, assigned a governor, and compelled to obey our laws by the emperor Trajan, who, by frequent victories crushed the arrogance of its inhabitants' (translation by J.C. ROLFE, in the Loeb Classical Library edition, 1939-1950).
} 
Twenty years after the military undertaking of Ælius Gallus, an inscription from Șirwāh, near Ma'rib, testifies to peaceful relations between the Nabataeans and Sabaeans. This bilingual (Sabaic/Nabataean) inscription is a dedication to a Nabataean deity, Dushara, dated to the third year of the Nabataean king Aretas IV - i.e. 7/6 BC - deposited in the temple of Almaqah, the tutelary deity of Saba' (NEBES 2006). Nebes does not preclude the establishment of a Nabataean trading post in the heart of the Sabaean kingdom at the turn of the Christian era (NEBES 2006: 10). Interestingly, it is also at that time that two people from the town of Maryamat (wādī Harīib), in the neighbouring kingdom of Qatabān, made a journey to the Nabataean kingdom and its main city, Petra. ${ }^{41}$

About $80 \mathrm{~km}$ north-east of Najrān, in the Sha ${ }^{\mathrm{i}} \mathrm{b}$ Șammā', another Nabataean inscription dated AD 88/89 testifies to the presence of a Nabataean possibly involved in the caravan trade (MACDONALD 1994). Nearby, in al-Khushayba, two graffiti of Nabataean anthroponyms have been reported (KAWATOKO et al. 2005: 132). The reason for their presence is unknown.

To sum up:

- Nabat was a region under Roman administration from the early 2nd century onwards; in the mid-3rd century, the presence of a community sharing common cultural traits and possibly a tribal identity was still recognized; this community might have experienced a political autonomy at the time of Riyām 2006-17, when the Roman Empire went through an unprecedented crisis.

- before its annexation, its territory stretched from southern Syria to Hegra in the Hijāz and from the Sinai Peninsula to Dümat al-Jandal to the east. In the 3rd century $\mathrm{AD}$, however, the extent of the 'land of Nabat' cannot be confirmed;

- before its annexation, the Nabataean kingdom was involved in a military expedition against the kingdom of Saba'; it also sustained commercial activities with South Arabian kingdoms.

\section{The land of the Romans}

Taking into account the location of the territories mentioned in the inscription, all located in the Arabian Peninsula, Near East, and Middle East, and especially the passing through of the Nabataean and Palmyrene areas, the formula 'land of Romans' probably means the Roman provinces of Arabia, Palaestina, and/or Syria-Phoenicia.

The military expedition headed by Ælius Gallus, prefect of Egypt, to Arabia Felix in 26/25 BC can be considered as the first political interaction between the South Arabian kingdoms and the Romans. Previously, Romans had been absent from local sources. Conversely, if South Arabia was well known as a provider of spices, it was until then a distant land, the products of which reached the Mediterranean through intermediaries. Therefore, the kingdom of Saba', though undefeated, might have been deeply distressed by the Roman foray that led to the destruction of the Sabaean city of Nashq and to the siege of its capital city, Marib. $^{42}$

\footnotetext{
${ }^{41}$ The journey reported in Maraqten-Qatabanic 1 was made 'in the territories and the towns of the North/Bilād alShām, and of Nabaț ${ }^{\mathrm{um}}$, Chaldea, Egypt, and Greece' (lines 9-10: 'r $r d t w w$-'hgr $S^{2} m t w-N b t^{m} w-K s^{2} d w-M s ̣ r w-$ Ywnm), and in 'the city of Petra' (line 12: hgrn Rqmm) (MARAQTEN 2014).

${ }^{42}$ Strabo (Geogr. XVI.4.24): 'he [Ælius Gallus] took the city called Asca [Nashq, present-day al-Bayḍā'], which had been forsaken by its king; and thence he went to a city called Athrula [Yathill, present-day Barāqish]; and, having mastered it without a struggle, he placed a garrison in it, arranged for supplies of grain and dates for his march, advanced to a city called Marsiaba [Maryab/Marib, present-day Ma'rib] (...). Now he assaulted and besieged this city for six days, but for want of water desisted'; Pliny (Nat. Hist. VI.32.17): 'Gallus destroyed the following towns, the names of which are not given by the authors who had written before his time, Negrana
} 
Two South Arabian inscriptions possibly refer to this event: a fragmentary Sabaic dedicatory inscription from the temple of Awām in Ma'rib mentioning the north $\left(s^{2} m t\right)$ and the Romans $\left(R m^{n}\right)$, as well as the undertaking of an expedition probably against the Romans; ${ }^{43}$ and a Qatabānic inscription from Tamna' mentioning 'the day when Romans (?) undertook an expedition' possibly in the kingdom of Qatabān. ${ }^{44}$

A Latin-Greek inscription has reportedly been found near Barāqish, the ancient city of Yathill, in the Jawf valley of Yemen; it reads: $[P($ ublius $)]$ Corne $[$ lius $]$... / eques ... in Latin and $\Pi$ ov $\beta \lambda \imath \varsigma$ Ko $\rho$... in Greek. ${ }^{45}$ If we agree with the identification of the city of $A \theta \rho o v \lambda \alpha-$ mentioned by Strabo (Geogr. XVI.4.24) and which has had been changed into a Roman garrison during the expedition of Gallus - as Yathill, ${ }^{46}$ the presence of a Latin inscription left by a Roman soldier would not be illogical, provided that it dates to the late 1 st century BC. ${ }^{47}$

Although Gallus' expedition was a failure, the tightening of the Roman presence in Arabia was felt both commercially and politically in the early Christian era. Both Strabo and the Periplus Maris Erythraei (CASSON 1989) describe the growth of maritime traffic in the 1st century between the Roman seaports of Egypt, Arabia, and India (SCHIETTECATTE 2012). In the 2nd century, Romans took over the northern and western fringes of the Arabian Peninsula. The annexation of the Nabataean kingdom had been mentioned previously (AD 106). The Latin inscription from the Farasān island, in the south of the Red Sea, dated c. AD 140-144, highlights the establishment of a detachment of the II Trajana Fortis legion and auxiliaries under the authority of a prefect of the portus of Ferresan (Farasān) and of the Sea of Hercules (the southern Red Sea) (PHILlips et al. 2004; VILLENEUVE et al. 2004). This extension of Roman presence in the Red Sea was probably driven either by a harsh customs policy or by the fight against piracy (VILLENEUVE et al. 2004: 169ff.).

During the 3rd century, there is no epigraphic mention of a connection between South Arabia and the Roman Empire except for Riyām 2006-17. A few decades later, in AD 311, another Sabaean diplomatic mission was dispatched to the Romans. ${ }^{48}$

To sum up:

- the land of the Romans can be understood as one or several of the eastern provinces of the Empire (Arabia, Palaestina, and/or Syria-Phoenicia);

[Nagrān, present-day Najrān], Nestum [Nashshān?, present-day al-Sawdā’], Nesca [Nashq, present-day al-Bayḍẩ’], Masugum, Caminacum [Kaminā, present-day Kamna], Labecia, and Mariva [Maryab/Marib, present-day Ma’rib].

${ }^{43}$ Inscription Ja 772/3-4 (JAMME 1962: 231), from the 1st century BC/AD according to the palaeography, reads '...] when they made an expedition against R[umān... $\left.{ }^{(4)} \ldots\right]$ north and Rumān $\left[\ldots{ }^{\prime}(b-](k) n s^{I}(b)^{\prime} b-{ }^{`} m R\left[m^{n} \ldots{ }^{(4)} \ldots\right.\right.$ ]$s^{2} m t w-R m^{n} w-[\ldots)$.

${ }^{44}$ Unpublished inscription T.02.B 22 (1st century BC/AD according to the palaeography): line 3: ' $\left.\ldots b-y\right] w m s^{l} b^{\prime}$ $R m\left[{ }^{n}\right.$...' According to Pliny (Nat. Hist. VI.32.17), Gallus went as far as Caripeta and destroyed this city. Caripeta can be identified as Haribat (present-day Hinū al-Zurayr), in Wādī Ḥarīb, in the heart of the kingdom of Qatabān.

${ }^{45}$ Inscription YM $605 \mathrm{kept}$ in the National Museum in Sanaa. According to its former owner, it comes from the neighbourhood of Barāqish (CosTA 1977: 69-70).

${ }^{46}$ See MÜLLER DH 1896: 2071.

${ }^{47}$ Costa assigned the inscription to the 3rd-4th century AD (COSTA 1977: 70); Villeneuve does not discard the possibility of a 2nd-century inscription (VILLENEUVE et al. 2004: 152, n. 44). Given that Barāqish was abandoned in the course of the 1st century AD (SCHIETTECATTE 2011: 57), an earlier date would be more appropriate (cf. BOWERSOCK 1983: 148-153 and MAREK 1994 who date it back to the 1st century BC). Contra this date and the hypothesis of a Roman soldier, see DEMOUGIN 1980: 165-167 who considers Eques as a simple cognomen and COSTA 1986 who favours a Roman trader.

${ }^{48}$ Unpublished Sabaic inscription MB 2004-I-123, dated AD 311, mentioning an embassy sent to 'Caesar [Constantine I] king of the North' (line 10: $\left.Q y s^{1} r^{m} m l k S^{2} m t\right)$; see n. 2. 
- from the 1st century onwards, direct maritime trade between southern Arabia and the Roman ports of Egypt experienced an unprecedented growth;

- the 2nd century AD is characterized by the tightening of Roman control over the Arabian fringes, be it the annexation of the Nabataean kingdom in AD 106 or the establishment of a prefect and a military contingent in the southern Red Sea;

- the 3rd and early 4th centuries are only characterized by two diplomatic missions sent to the Roman territories by the lords of Bata ${ }^{c}$ and Hamdān and then by a Himyarite king.

\section{The land of Lakhm}

Riyām 2006-17 is the first of the South Arabian inscriptions to mention this tribe. Lakhm is an Arab tribe associated in Ibn al-Kalbī's genealogical tree to two sister-tribes, 'Âmila and Judhām (CASKEL 1966, I: table 176). In early Islam, Lakhm had been absorbed by Judhām, fighting under the same leader and banner (LAMMENS \& SHAHÎD 1986: 636). The fame of this tribe rests on the prominent role of the Lakhmids as kings of al-Hirra during the pre-Islamic period. Two documents refer to a certain 'Amr king of $\mathrm{Lakhm}^{49^{\circ}}$ who is identified as 'Amr b. 'Adī b. Nașr, founder of the Nașrid dynasty of the kings of al-Hīra (RoBIN 2008: 190-191). His reign is dated c.293-302. This dynasty had been given the government of the Lower Euphrates by Sasanian rulers. Robin convincingly makes the assumption that they did not rule the territory of Lakhm - a tribe located elsewhere - but rather the main tribes of the Lower Euphrates area, including Tanūkh (ROBIN 2008: 193). ${ }^{50}$

Assuming that the situation in the 3rd and 6th centuries did not evolve very much, the location of the tribe of Lakhm is more likely to be found in the desert margins of southern Syria, eastern Jordan, and north-western Arabia. This is based on the fact that the tribe of Judhām, which was closely connected to that of Lakhm - before absorbing it — was 'settled in pre-Islamic times on the borders of Byzantine Syria and Palestine; they held places like Madyan, 'Ammān, Ma āan, and Aḍhruḥ, and ranged as far south as Tabūk and Wādī '1-Ḳurā' (BOSWORTH 1965: 588; see also CASKEL 1966, II: 264).

Consequently, the Lakhmid territory as described from the late 3rd century onwards would have overlapped the territories previously belonging to the Nabataeans. It cannot be confirmed whether these peoples either shared a common land as neighbours, or that one was enclosing the others, or that one was progressively replacing the others.

To sum up:

- Lakhm was a tribe the past fame of which caused its rulers to be appointed by the Sasanian kings to rule the area of al-Hīra as well as the tribe of Tanūkh;

— in the 3rd century AD, the heartland of Lakhm could be found in the desert fringes spreading from southern Syria to the Tabūk area, in north-western Arabia, in an area previously peopled with Nabataeans and possibly Lihyanites, thus sharing their territory or superseding them;

\footnotetext{
${ }^{49}$ The bilingual Pehlevi/Parthian inscription from Paikūlī (Kurdistan), dated after AD 293 and mentioning "Amr king of Lahmay [Lakhm]' (Pehlevi: ' $m[r w]$ Lhm'dyn ML(KA); Parthian: 'mrw Lhmyšn MLKA); a Manichaean text in Coptic mentioning 'Amarō, king of the sons of Lahim [Lakhm]' (Amarō p-r[ro n-n-sēre n-L]ahim) (TARDIEU 1992; see also RoBIN 2008 with references).

${ }^{50}$ The same situation occurs in the 6th century $\mathrm{AD}$ when the government of the tribe of Ma'add is given to the princes of the tribe of Kinda by the Himyarite kings; or when the Byzantine emperors made the leaders of the tribe of Ghassān rulers of Muḍar (RoBIN 2008: 189).
} 
- closely connected to the tribes of 'Āmila and Judhām, Lakhm was eventually incorporated within the tribe of Judhām on the eve of Islam.

\section{The land of Ghassān}

Ghassān is a tribe that enjoyed great fame in late antiquity. The fate of Ghassān has been recently reported in detail in several studies (AVNER et al. 2013; ROBIN 2008, 2015). The most significant elements are summarized below.

Ptolemy (Geogr. VI.7.6) points to Kassanitôn chôras between Kinaidokolpitôn chôras on the Red Sea coast, north of the Farasān islands, and Elisarôn choras on the Red Sea coast of Yemen. The identification of Kassanitôn with Ghassān is likely but not certain (RoBIN 2008: 191). Ghassān can also be compared to the gentes Casani mentioned by Pliny (Nat. Hist. VI.32.8) in the same area. ${ }^{51}$

According to Arab tradition, the name Ghassān stems from a watering place where clans who had freed themselves from the tribe of al-Azd (IBN HAZM, Jamharat ansāb al-'Arab: 472) came to quench their thirst (IBN HAZM, Jamharat ansāb al- 'Arab: 462; IBN AL-KALBI, Nasab Ma add: 362). It is worth noting that al-Hamdānī locates the place Ghassān in the Yemeni Tihāma (CASKEL 1966, II: 273), not far from the location of Ptolemy's Kassanitôn and Pliny's Casani; moreover the tribe al-Azd from which the clans of Ghassān would have proceeded, is located in the 'Asīr region, which towers above the Tihāma plain.

Considering the reserve which is shown about the tale of the origins of Ghassān in medieval accounts (CASKEL 1966, II: 273; ROBIN 2015: 83-84), and the chronological gap between classical sources and Arab tradition, however, a location of Ghassān on the Red Sea coast at the turn of the Christian era remains hypothetical, all the more since in the following centuries this tribe is precisely located further north.

In the 3rd-4th century, the territory of Ghassān was clearly spreading in the Hijāz, from Qați ${ }^{`} \mathrm{a}, c .60 \mathrm{~km}$ south-east of al-'Ulā, ${ }^{52}$ down to the wells of Sijā, $380 \mathrm{~km}$ north-east of Mecca $^{53}$ (RoBIN 2008: 191; 2015: 99-102). The oasis of Yathrib (modern Medina) lies in the very heart of this area and could have been the capital of Ghassān (ROBIN 2015: 102). ${ }^{54}$

Two documents indicate that Ghassān was a tribal kingdom ruled by a king in the 3rd century:

- the Sabaic inscription ZI 75, c. AD 240-255, where Ilissharah Yahdub king of Saba' and dhū-Raydān dispatched an embassy to the kings of the tribes of Ghassān, al-Azd, Nizārr ${ }^{\text {um }}$, and Madhhịg ${ }^{\text {um, }}$

— the transitional Nabataean inscription of 'Hārithat son of Zaydmanōtū king of Ghassān' (inscription 'Dhuyayb 2005 no. 65').

\footnotetext{
${ }^{51}$ Another identification of the Casani with the toponym Jīzān, opposite the Farasān islands in the Tihāma plain, has been suggested elsewhere (VILLENEUVE et al. 2004: 159 n. 78).

52 At Qațî'a, the rock inscription 'Dhuyayb 2005 no 65' is written in a transitional script, between Nabataean and Arabic. Dated to the 3rd century AD according to palaeography (L. Nehmé, pers. com.), it mentions 'Hārithat son of Zaydmanōtū king of Ghassān' (Hrtt br Zydmnwtw mlk 'sn) (AL-DHUYAYB 2005: 65). It is highly likely that the inscription was carved in a location where the authority of the king was acknowledged.

${ }^{53}$ We have already mentioned the Sabaic inscription 'Abadān 1/29, dated to AD 360, where the border between the land of Nizārr ${ }^{\text {um }}$ and that of Ghassān is said to go through the wells of Sijā (cf. the land of Nizār).

${ }^{54}$ The presence of a Ghassānid lineage in Yathrib (the banū Tha'laba) on the eve of Islam (RoBIN 2008: 189; 2015: 93) tallies with this hypothesis.
} 
Around the 5th century AD, the tribe of Ghassān broke up into small groups, dispersing from Yathrib to the Euphrates valley. ${ }^{55}$ By the end of this century, some of its chiefs, descending from the lineage of Tha'laba (banū Tha'laba) and from that of Jafna (banū Jafna) entered Byzantium's service (ROBIN 2008; 2015: 103-107; AVNER et al. 2013). The dignity of phylarch and king had been bestowed on them after treaties were negotiated; they had military and financial responsibilities and their authority was exerted on Arab groups settled in the Byzantine territory (province of Arabia, Phoenice Libanensis, Palaestina I, II, and III), which no longer corresponded to the old tribe of Ghassān (AVNER et al. 2013: 252-253).

At the start of the Islamic period, Ghassān was no more than a broken-up tribal group with no continuous territory.

To sum up:

- classical sources and Arab tradition point to an origin of the tribe of Ghassān in southern Tihāma, which is far from certain;

— in the 3rd century AD, Ghassān was a tribe ruled by a king, which spread over the central Hijāz, from Sijā to the south of al-'Ulā; diplomatic relations were exchanged with the Sabaean kingdom;

— in the late 5th and almost all the 6th century AD, while the tribe of Ghassān had no more territorial hold, some of the leaders of prestigious lineages from this tribe were appointed kings or phylarchs by Byzantium and were in charge of buffer territories between the core of the empire and external threats, primarily the Persians.

\section{The land of $\mathrm{Ma}^{\mathrm{c}}$ add}

Ma'add designates a population living in Central Arabia, regarded either as a wide tribal confederacy (ROBIN 2008: 174) or as a 'general population of predominantly camel-herding Arab bedouins and bedouin tribal groups - irrespective of lineage or place of origin - who ranged, encamped, and resided throughout most of the central and northern peninsula' (ZWETTLER 2000: 285). The sources, history, and extent of this tribe have been collected and synthesized (ZWETTLER 2000; ROBIN 2008: 173-176). It emerges that from the 4th to the 6th century, Ma'add was rarely politically independent but was rather contingent on surrounding powers.

On his funerary inscription from al-Namāra (AD 328), Mara'-1-Qays 'king of all 'Arab' is said to have 'ruled Ma'addū' (line 3). One can presume that since it was submitted in the early 4th century AD, Ma'add was previously independent, a status that Riyām 2006-17 does not contradict.

Later, Macadd was at the heart of successive conflicts. From AD 340 to 360, Himyarite expeditions were carried out against Ma add and its territory. ${ }^{56}$ A century later, the Himyarite kings Abīkarib As'ad and his son Ḥaśśān Yuha'min took possession of the land of Ma'add, with the help of the tribe of Saba', Hadramawt, and the Arabs of Kinda, celebrating the event

\footnotetext{
${ }^{55}$ RoBIN 2015. This break-up might have taken place as early as the late 4th century: in AD 363, Ammianus Marcellinus reports that Persians and 'a man named Malechus Podosaces, the chief of the Assanite [Ghassanite] Saracens [Arabs]' laid an ambush for the Roman army along the Euphrates river (Roman Hist. XXIV.2.4).

${ }^{56}$ The Sabaic inscription 'Abadān 1 reports four campaigns in Central Arabia, two of them aiming explicitly at Ma add, one in $c$. AD 340 reached Yabrīn (lines 6-10); a second in $c$. AD 345 (lines 12-16); a third in $c$. AD 350 was carried out against nomad tribes ( ${ }^{c} s^{2} r^{m}$ ) of Ma add and reached Khargān (the valley of al-Kharj) and Gawwān (city of Jaw al-Yamāma in this valley) (lines 17-21); a fourth $c$. AD 360 was an expedition against Ma'add and groups of the tribe of 'Abd al-Qays. For the transcription and translation see RoBIN \& GAJDA 1994. On the identification of toponyms and their insertion within the territory of Ma'add see ROBIN \& GAJDA 1994: 123; ROBIN $\&$ ARBACH, in press.
} 
at Ma'sal Jumh, c.200 km west of Riyadh. ${ }^{57}$ In AD 521, the Ḥimyarite king Ma dīkarib Ya ${ }^{c}$ fur launched an expedition from the same location of Ma'sal Jumb against al-Mundhir (III) king of al-Hīra, thus highlighting the maintenance of the Himyarite control of $\mathrm{Ma}^{\mathrm{c}}$ add, through the princes of Kinda. ${ }^{58}$ Following the death of the Kindite al-Hārith (c. AD 528), Ma'add sided with al-Mundhir (III), king of al-Ḥira (CAUSSIN DE PERCEVAL 1847-1848, II: 301-302), together with tribes from north-east Arabia including Țayy (see below). Eventually Ma'add, the government of which had been bestowed on 'Amr son of al-Mundhir (III), was defeated in AD 552 at Halibān by the troops of Abraha, the Aksumite-born king of Himyar. ${ }^{59}$ By the end of the 6th century $\mathrm{AD}, \mathrm{Ma}^{\text {cadd }}$ had disappeared, giving way to the tribal confederacy of Rabī'a (RoBIN 2008: 174). ${ }^{60}$

Sources regarding the extent of the territory of Ma'add are mainly relevant for the 4th-6th century AD. It was then centred on Ma'sal al-Jumh and reached Yabrīn to the south-east, Halibān to the south-west, Baṭn 'Āqil and the wādī al-Ruma to the north, where Hujr b. 'Amr pitched camp, and included the valley of al-Kharj to the east (ROBIN 2008: 174; ROBIN \& ARBACH, in press: fig. 80).

A revolt by the Banū 'Āmir/ ${ }^{\circ} A m{ }^{61}$ led to an expedition by Abraha against Ma'add and the princes of Kinda. If we are to identify the Banū 'Āmir/'Amr as the tribe of the banū 'Āmir b. Șa ${ }^{c} a^{c} a$, their territory — which spread somewhere between Mecca and Ma'sal al-Jumh was then part of Ma'add. This hypothesis, generally accepted, has been recently disputed by Robin who is rather inclined to identify the Banū 'Amr with the lineage of the banū 'Amr b. Mu'āwiya, given by the Arab tradition to the princes of Kinda descended from Hujr b. 'Amr (ROBIN 2012c: 81). If this is correct, the western limit of Ma'add cannot be deduced from Ry 506. Be that as it may, in the mid-6th century, this territory might have stretched as far as the coast of the Red Sea according to Procopius of Caesarea. ${ }^{62}$

At the time of Riyām 2006-17 (3rd century), because of the presence of the tribes of Ghassān, Asd, and Nizār west of $\mathrm{Ma}^{\prime}$ add, such an extent cannot be conceived; it was probably limited to Central Arabia.

To sum up:

- Ma'add is a 'socio-ethnic label applied to a specific category of Arab bedouins' (ZWETTLER 2000: 289) or perhaps a tribal principality, which could have enjoyed independence in the 3 rd century $\mathrm{AD}$;

\footnotetext{
${ }^{57}$ The Sabaic inscription Ry 509, re-edited in RoBIN 1996: 675-685. Ma’sal Jumh was most probably the central place of Ma ${ }^{c}$ add (RoBIN 2008: 187-189).

${ }^{58}$ The government of Ma'add had been conferred by Abīkarib As'ad and his son Hasśśān Yuha'min to the prince of the tribe of Kinda, Hujr bin 'Amr — known in Arab tradition as Ākil al-Murār — and then passed on to his descendants, the banū Hujr: his son 'Amr, his grandson al-Hârith (Arethas in the Byzantine sources) and then to Qays (Kaïsos in the Byzantine sources) probably a grandson of al-Ḥārith (GAJDA 1996; RoBIN 1996; 2008: 173$176 ; 2012 \mathrm{c})$.

${ }^{59}$ Reported in Sabaic inscriptions Ry 506 = Murayghān 1 and Murayghān 3 (RoBIN \& TAIRAN 2012). Hialibān is located $90 \mathrm{~km}$ west-south-west of Ma’sal al-Jumḥ.

${ }^{60}$ Incidentally, it is worth noting that the genealogical tree of Arab tribes mentions Rabī ${ }^{`} a$ as descending from Nizār b. Ma'add (CASKEL 1966, I: table 1).

${ }^{61}$ The bny ' $m r^{m}$ mentioned in the Sabaic inscription Ry 506 from Murayghān.

${ }^{62}$ Procopius, Hist. of the Wars I.XIX.14: 'Adjoining this people [the inhabitants of the Palm Groves = the main oases of the Hijāz] there are other Saracens [Arabs] in possession of the (Red Sea) coast, who are called Maddeni [Ma' add] and who are subjects of the Homeritae [Himyarites]'.
} 
- from the 4th century AD onwards, willingly or by force, it entered different political spheres: after it was subjugated by Mara'-1-Qays king of all 'Arab, it became a trust territory of Himyar governed by the princes of Kinda, and temporarily acted as a buffer zone between Himyar and the kingdom of al-Hīra, under the latter's authority;

- the territory of Ma'add was primarily a region of Central Arabia. In the 6th century AD it was centred on Ma'sal al-Jumh and stretched to the west, possibly as far as the Red Sea coast.

\section{The land of Tayy}

Țayy $^{\text {um }}$ is identified as the Arab tribe Țayyi' from the northern Najd.

Caskel proposed the hypothesis that this tribe might be the one mentioned in Pliny's description of North Arabia under the name Taveni (CASKEL 1966, II: 555), a people said to have settled next to the Nabataeans, and listed together with the Taymanites, the inhabitants of Arra, and the cities of Dümat al-Jandal and Hegra, all in northern Arabia. ${ }^{63}$ If the identification is not certain, it would be consistent with the location proposed subsequently.

Some of the oldest secure references to Țayyi' appear in the corpus of Safaitic inscriptions. ${ }^{64}$ Safaitic script does not seem to have been used after the 4th century AD (MACDONALD 2000: 45 ); it provides us with a terminus ante quem for these references.

In Sabaic inscriptions, Riyām 2006-17 apart, Tayyi appears only once in inscription Murayghān 3, dated to the reign of the Himyarite king Abraha (mid-6th century AD). It commemorates a successful expedition of Himyarite armies against the tribe of Ma'add as well as the submission of the Arab tribes from Hijāz, North and East Arabia, among these the Tayyi' (ROBIN \& TAIRAN 2012). ${ }^{65}$ This expedition follows a request by the Byzantine emperor Justinian to Abraha who was summoned to attack the Persians (Procopius, Hist. of the Wars I.XX.9-10.). A few years earlier, the tribe of Țayyi' had sided with al-Mundhir (III) king of al-Hiira, under the umbrella of the Persians (CAUSSIN DE PERCEVAL 1847-1848, II: 301-302).

Thus, in late antiquity, Tayyi' is one of the main tribal entities in the Peninsula. In this respect, it is significant that Syriac sources of the late pre-Islamic period used the word Tayaye to designate all the Arabs, which clearly derives from the name of the tribe Tayyi' and highlights the prominent role it played in North Arabia. ${ }^{66}$

\footnotetext{
${ }^{63}$ Pliny, Nat. Hist. VI.32.14: 'Adjoining the Nabataei [Nabataeans] the old authorities put the Timanei [Taymanites], but now there are the Taveni [Țayyi'?], Suelleni, Araceni [Saracens], Arreni [Arre Kóme mentioned by Ptolemy Geogr. VI.7.30, next to Salma which is identified as Jibāl Salmà next to Ḥâàil] with a town which is a centre for all mercantile business, Hemnatae, Avalitae [Hawlat] with the towns of Domata [Dūmat al-Jandal] and Haegra [Hegra, present-day Madā’ in Șāliḥ]'.

${ }^{64}$ M.C.A. Macdonald points out the existence of at least 13 Safaitic inscriptions which mention encounters with Țayyi' (M. Macdonald, pers. com.), e.g. CIS V 2795, from az-Zalaf area, $18 \mathrm{~km}$ south-east of Tulūl al-Ṣafā (southern Syria), where a man called $T m \ldots$ is grieving for his companions who were raiding the tribe of Tayyi' $\left(T y^{\prime}\right)$ (MACDONALD 2004: 527).

${ }^{65}$ Murayghān 3/3-4: " (3) quand il s'empara des Arabes de Ma'add ${ }^{u m}$ enlevés à [Mu]dhdhirān, chassa 'Amr ${ }^{u m}$ fils de

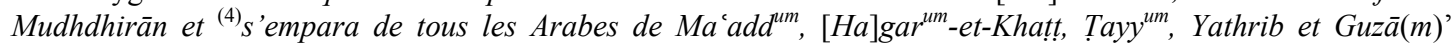
(translation by ROBIN \& TAIRAN 2012: 528).

${ }^{66}$ See the Chronicle of Pseudo-Joshua the Stylite and the use of the formula 'the Arabs of the Persians' (Tayzyê da-Pûrsoyê) and 'the Arabs of the land of Romans' (Tayayê do-bêt Rahûmoyê) (Wright 1968: 15; AvNER et al. 2013: 245; ROBIN 2008: 170).
} 
In the Arab tradition, the tribe of Tayyi' would have settled in Jibāl Ajā', Jibāl Salmà, and in the plain in between, at the latest in the 6th century $\mathrm{AD} .^{67}$ These two mountains, also called 'the two mountains of Tayyi' are known today as Jabal Shammar. Jibāl Salmà are a basaltic formation located $60 \mathrm{~km}$ south-east of the modern city of $\mathrm{H}_{\bar{a}} \mathbf{i l}$; Jibāl Ajầ are a granitic mountain range immediately west of this town. Ibn al-Kalbī said Țayyi' had an idol called alFals in Jibāl Ajāa' (FARIS 1952: 51). The western extent is only known in the 10th century AD, at a time when Taymā' was part of its territory (AL-HAMDĀNi Șifa, I.131; ABŪ AL-FIDĀ' Géogr., II.117).

To sum up:

- Tayyi' is an Arab tribe from northern Najd, possibly attested from the 1st century AD onwards if it corresponds to the Taveni mentioned in North Arabia by Pliny;

- it was soon an important tribe in North Arabia (Riyām 2006-17) and people from Țayyi' made incursions into southern Syria according to a Safaitic inscription;

- in the 6th century AD, it played a prominent role in the political landscape, either in Sabaic inscriptions, Syriac sources, or the Arab tradition.

\section{The land of Khașạsat}

Documentation is lacking on the land of Khașāșat ${ }^{\text {ān }}$. Besides Riyām 2006-17, the only mention is found in the Sabaic inscription Ja 576+577, from the temple of Awām in Ma'rib. The text, dated to the reign of Ilīsharah Yahdub and Ya'zil Bayān kings of Saba' and dhūRaydān (c. AD 235-255), mentions a certain Mara'-1-Qays (Mr'lqs ${ }^{I}$ ) son of 'Awf ${ }^{\text {um }}$ king of Khașāsatat ${ }^{\text {an }}$, who is seen as a subordinate of the kingdom of Kinda (BEESTON 1973: 450) and who was surrendered to the Sabaean king.

M. Rodinson speculated about a North Arabian origin of Khașāṣat ${ }^{\text {an }}$ after the name of its king (RODINSON 1957: 115). This statement is unfounded and the close political proximity with the kingdom of Kinda - then centred on the city of Qaryat al-Fāw - favours a location nearby.

In Ibn al-Kalbī's genealogical tree of the Arab tribes, al-Khașașa descends from Duhmān, a branch of the tribe of Zahrān, a faction of al-Azd (CASKEL 1966, I: table 217). According to Robin, Duhmān is known today as Dahm (RoBIN 2013: n. 23), a tribe from the northern Jawf (Yemen); Zahrān is a tribe from western 'Asīr (south-west Saudi Arabia), c.200 km south-east of at-Ta â' if and $120 \mathrm{~km}$ west of Bīsha. Therefore, the land of Khașāșat ${ }^{\overline{a n}}$ was probably located somewhere next to the land of Asd and the Kindite area, most probably in the 'Asīr heights.

To sum up:

- Khașāṣat ${ }^{\mathrm{a} n}$ was an autonomous entity ruled by a king and closely connected to the kingdom of Kinda in the 3rd century AD;

- it is a land probably located in what is now the al-Bāha or 'Asīr province of Saudi Arabia.

\section{Unquoted political entities: Himyar, Hadramawt, Aksum, and Kinda-and-Madhhij}

The account of the diplomatic mission carried out on behalf of the Sabaean lords of Bata ${ }^{c}$ and Hamdān, rulers of the tribe of Humlān and Hâshid, does not mention the great powers which

\footnotetext{
${ }^{67}$ On the settling of Țayyi' in this area, see YĀQūT, Mu'jam al-buldān I.122-130; CAUSSIN DE PERCEVAL 18471848, I: 102. See also the mention of 'Tayyi' of the twin mountains' in the pre-Islamic poem by Bishr ibn Abū Khāzim (LyALL 1918-1924, II: 279, verse 24).
} 
directly surrounded Saba': the kingdom of Himyar to the south, the kingdom of Hadramawt to the east, the kingdom of Aksum to the west, and the tribe of Kinda-and-Madhhij to the north.

If the inscription is dated to the end of, or just after, the reign of Nasha'karib Yu'min Yuharhib - a position defended by the present authors (ARBACH \& SCHIETTECATTE, in press) - this absence could be explained by the fact that the kingdom of Saba' was at war against these immediate neighbours some time during that reign or just afterwards.

An expedition is reported against the Abyssinians west of the kingdom of Saba' ${ }^{68}$ Three inscriptions mention one or several conflicts against the kingdom of Hadramawt. ${ }^{69} \mathrm{~A}$ war is reported against the tribe of Khawlān Gudādum and several tribes from the north of modern Yemen (i.e. the tribes of Daw'at, ' $b$ 's $s^{1}$, Aydā'ān, Hakam ${ }^{\text {um }}$, Hidginat, Ghāmid ${ }^{\text {um }}$, Kahl ${ }^{\mathrm{um}}$, AhlNāh, Gadīlat, Sibbis ${ }^{\text {um }}$, Harīm ${ }^{\text {um }}$, Hagūr $L m d$, Awām ${ }^{\text {um }}$, and $R d h h^{n}{ }^{n}$ b. Hurrat) ${ }^{70}$ Eventually, the rivalry between the kingdom of Saba' and that of Himyar ended in the annexation of the first by the second and to a war of resistance led by the lords of Bata ${ }^{c}$ and Hamdān. ${ }^{71}$

A conflict between Saba' and the tribe of Kinda-and-Madhhij at the time of Nasha'karib Yu'min Yuharhib cannot be confirmed. It can only be stated that during the reign of his father Ilīsharah Yahḍub, an expedition against Malik ${ }^{u m}$ king of Kinda and his capture is reported (Ja 576+577/1-2). The reason for the silence of Riyām 2006-17 about this tribe could be either that the king of Saba' was then the overlord of this tribe, or that a conflict set the Sabaeans and this tribe against each other; both these hypotheses rule out the prospect of a diplomatic mission.

Be that as it may, the obvious conflictual situation of the Sabaean kingdom in the late 3rd century would easily explain the ambitious diplomatic mission initiated by the lords of Bata and Hamdān.

\section{Conclusion}

Thanks to the discovery of Riyām 2006-17, the political map of Arabia in the 3rd century can be quite confidently drawn. The Peninsula appears then as a composite territory surrounded by the great powers of the Sasanian and Roman empires to the north, and by the kingdom of Aksum to the south-west.

The southern part of the Peninsula, the Arabia Felix of the classical sources, was divided between three kingdoms made up of a confederation of sedentary tribes: Saba' to the northwest, Himyar to the south-west, and Hadrramawt to the east.

\footnotetext{
${ }^{68}$ Ir 20/1: 'H'n [......] officer of Nasha'karib Yu'min Yuharhị, king of Saba' and dhū-Raydān (...) carried on an expedition to the west, by the order of their lord, the king, and they came back with spoils and prisoners and booty (taken) from the Abyssinians' ( ${ }^{(1)} H^{\prime} n[\ldots \ldots]$ mqtwy $N s^{2^{\prime}} k r b Y^{\prime} m n$ Yhrḥb mlk $S^{l} b^{\prime} w-\underline{d}-R y d n$ (...) $s^{I} b^{\prime} m^{\prime} r b n$ b-qht $m r^{\prime}-h m w$ mlkn w-'tww b-'hllm w-s'bym w-ginmm bn 'hbs ${ }^{2} n$ ) - CSAI's translation.

${ }^{69}$ Ir 21/1-2: 'Almaqah Thahwān, Lord of Awwam, granted His servant Karib 'athat Az'ad of the family of Sahr to kill a man and to seize his horse, ${ }^{(2)}$ when they performed service with their lord Nasha'karib Yu'min Yuharhib, king of Saba' and dhü-Raydān, when he came to the rescue against the army of the Hadramawt' ('Imqh Thwn $b^{\prime}$ '-

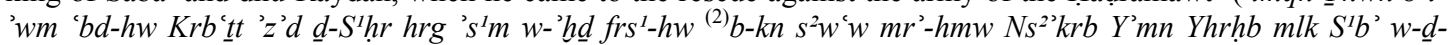
Rydn b-kn h'n b-'ly mssr Hḍrmwt) - CSAI's translation.
}

Ja 612/1-10: 'Ahmad Yughnim son of Nasha'y, lieutenant ${ }^{(2)}$ of Nasha'karib Yu'min Yuharhib, king ${ }^{(3)}$ of Saba' and dhū-Raydān $(\ldots)^{(8)}(\ldots)$ undertook ${ }^{(9)}$ the military expedition and followed the qayls and the army force to the land

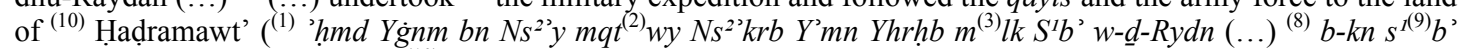
$w-S^{2} w^{\prime} n$ 'q $w \ln w-h m s^{I} n$ ' $d y$ 'r $r{ }^{(10)} H d \underline{d r m t}$ ) - CSAI's translation.

FB-al-Bayḍā' 1/7-8: 'during the war between the kings ${ }^{(8)}$ of Saba' and Hadramawt' (b-dr kwn bn 'ml $l^{(8)} k S^{l} b^{\prime} w$ $H d i r m t)$ - after Bron's translation (BRON 2010: 166).

${ }^{70} \mathrm{Ja}$ 616+622/12-26. Recent translation and comment by RoBIN 2014: 170-172, 191-194.

${ }^{71}$ Inscription CIH 353. 
In between, the vast area of the Najd and Hijāz — the Arabia Deserta of the classical sources - was peopled with at least eight autonomous tribal groups comprising sedentary and nomadic populations, from north to south: Țayy, Lihyyān, Ghassān, Ma'add, Nizār, Asdān, Khașāșatān, and Kinda-and-Madhhij. In the 3rd century, the title of king (malik) was bestowed on the rulers of most of these tribes. This is certain for Ghassān, Nizār, Asdān, Khașāṣatān and Kinda-and-Madhhịi, and probable for Ma' add.

North of the Peninsula, the desert margins of the Roman and Sasanian empires were occupied by tribal groups and client kingdoms (Nabat, Lakhm, Tadmur/Palmyra, Tanūkh). The crisis of the Roman Empire in the 3rd century made it possible for some of its territories to claim a kind of political autonomy. This was the case in Palmyra for a decade (263-272), it might have been the case for the land of Nabat.

Be that as it may, the map of Arabia that is presented here remains a snapshot of a given time (possibly c. AD 260). The tribe outlines are volatile according to changing alliances of tribal groups, allegiances, or annexations. The expansion of Himyar in the Arabian Peninsula from the 4th century AD onwards was a decisive agent in the rapid transformation of the political landscape in the Peninsula from then on. This explains why the political map in the 3rd century differs from that of the early 2 nd century AD drawn by Claudius Ptolemy (KENNEDY 2002: map 15A) or from that of the 5th-6th century AD (RoBIN 2008: fig. 1). It also explains why it is important to define this missing link.

\section{Jérémie SCHIETTECATTE}

CNRS, UMR 8167 'Orient \& Méditerranée'

27 rue Paul Bert

94204 Ivry-sur-Seine cedex, France

j.schiettecatte@cnrs.fr

\section{Mounir ARBACH}

CNRS-MAEDI, USR 3141 Centre français d'archéologie et de Sciences sociales

Riyadh, Arabie Saoudite

mounirof@yahoo.fr

\section{Acknowledgements}

The authors are indebted to Astrid Emery, Helen Knox, Michael Macdonald (University of Oxford), Laïla Nehmé (CNRS, Paris), and Christian Robin (CNRS, Paris) for reading a draft of the article and providing valuable comments and suggestions. Any error remains our sole responsibility.

\section{Sigla}

For the bibliographic references of the South Arabic inscriptions mentioned in the text, see KITCHEN 2000 and the on-line corpus of the South Arabian inscriptions displayed in the Digital Archive for the Study of Pre-Islamic Arabian Inscriptions (http://otto.sns.it/dasi_web). 
Version auteurs (pre-print) - J. Schiettecatte \& M. Arbach, 2016. « The political map of Arabia and the Middle East in the third century AD revealed by a Sabaean inscription », Arabian Archaeology and Epigraphy, 2016, 2: 176-196.

\section{References}

ABŪ AL-FIDĀ'

1848. Géographie d'Aboulféda [Abū al-Fidā'] traduite de l'arabe en français et accompagnée de notes et d'éclaircissements par M. Joseph-Toussaint Reinaud. Paris.

ABU AL-HaSAN H.

2010. Le royaume de Lihyân. In A.I. AL-GHABBÂN, B. ANDRÉ-SALVINI, F. Demange \& M. CotTy (eds.), Routes d'Arabie: Archéologie et histoire du royaume d'Arabie Saoudite. Paris, Musée du Louvre/Somogy: 270-285.

AMmianus MARCELLINUS/Transl. C.D. YounGE.

1911. Roman history of Ammianus Marcellinus during the reigns of the emperors Constantius, Julian, Jovianus, Valentinian, and Valens. London: G. Bell and Sons.

ANTONINI S. \& ROBIN C.

2015. Two silver vases of Greco-Roman style from the "treasure of wādi Dura", (Yemen). In M. Arbach \& J. Schiettecatte (eds.), Pre-Islamic South Arabia and its neighbours: new developments of research. Proceedings of the 17th Rencontres Sabéennes held in Paris, June 6-8, 2013. (BAR, International Series, 2740). Oxford, Archaeopress: 3-12.

ARBACH M. \& SCHIETTECATTE J.

2012. Inscriptions inédites du Jabal Riyām des VII ${ }^{\mathrm{e}}-\mathrm{VI}{ }^{\mathrm{e}}$ siècles av. J.-C. In A. Sedov (ed.), New research in Archaeology and Epigraphy of South Arabia and its Neighbors. Proceedings of the 'Rencontres Sabéennes 15' held in Moscow May 25th-27th 2011. Moscow: 37-68.

In press. De la diplomatie et de l'aristocratie tribale du royaume de Saba' d'après une inscription du $\mathrm{III}^{\mathrm{e}}$ siècle de l'ère chrétienne. Comptes rendus de l'Académie des Inscriptions et Belles-Lettres, 2015/1.

AVNER U., NEHME L. \& ROBIN C.

2013. A rock inscription mentioning Tha 'aba, an Arab king from Ghassān. Arabian Archaeology and Epigraphy 24: 237-256.

\section{BEESTON A.F.L.}

1954. Notes on Old South Arabian lexicography VI. Le Muséon 67: 311-322.

1973. Notes on Old South Arabian lexicography VIII. Le Muséon 86: 443-453.

\section{BOSWORTH C.E.}

1965. Djudhām. In Encyclopédie de l'Islam II. Leiden, Brill: 588.

BOWERSOCK G.W.

1983. Roman Arabia. Cambridge, MA: Harvard University Press.

\section{BRIQUEL-CHATONNET F.}

2010. Les graffiti en langues nord-sémitiques de Bir 'Alī (Qāni'). In J.-Fr. Salles \& A.V.Sedov (eds.), Qāni'. Le port antique du Haḍramawt entre la Méditerranée, l'Afrique et l'Inde. Fouilles russes 1972, 1985-1989, 1991, 1993-1994. (Indicopleustoi, Archaeologies of the Indian Ocean). Turnhout, Brepols: 387. 
Version auteurs (pre-print) - J. Schiettecatte \& M. Arbach, 2016. « The political map of Arabia and the Middle East in the third century AD revealed by a Sabaean inscription », Arabian Archaeology and Epigraphy, 2016, 2: 176-196.

\section{BRON F.}

2010. Nouvelles inscriptions sudarabiques. Semitica et Classica 3: 163-175.

BRON F. \& LEMAIRE A.

2009. Nouvelle inscription sabéenne et le commerce en Transeuphratène. Transeuphratène 38: 11-29.

\section{CASKEL W.}

1954. Lihyan und Lihyanisch. (Arbeitsgemeinschaft für Forschung des Landes Nordrhein-Wesfalen. Geisteswissenschaften, 4). Cologne: Westdeutscher Verlag.

1966. Ğamharat an-nasab. Das genealogische Werk des Hišam Ibn Muhammad alKalbī. Leiden: E.J. Brill.

\section{CASSON L.}

1989. The Periplus Maris Erythraei: Text with Introduction, Translation, and Commentary. Princeton: Princeton University Press.

\section{Caussin de Perceval A.P.}

1847-1848. Essai sur l'histoire des Arabes avant l'islamisme, pendant l'époque de Mahomet et jusqu'à la réduction de toutes les tribus sous la loi musulmane. (3 vols.). Paris.

CLARK V.A.

1979. A Study of New Safaitic Inscriptions from Jordan. PhD thesis, Department of Middle Eastern Studies, University of Melbourne. Ann Arbor, MI: University Micro-films International.

\section{Costa P.}

1977. A Latin-Greek inscription from the Jawf of the Yemen. Proceedings of the Seminar for Arabian Studies 7: 69-72.

1986. Further comments on the bilingual inscription from Barāqish. Proceedings of the Seminar for Arabian Studies 16: 33-36.

\section{DEMOUGIN S.}

1980. Eques: un surnom bien romain. Annali del seminario studi del mondo classico. Sezione di archaeologia e storia anticha 2: 157-169.

\section{AL-DHUYAYB S.}

2005. Nuqūsh nabațiyya fí 'l-Jawf, al-'Ulā, Taymä', al-mamlaka al-'arabiyya alsa'üdiyya. Riyadh.

\section{EDWELL P.M}

2008. Between Rome and Persia: the middle Euphrates, Mesopotamia and Palmyra under Roman control. (Routledge monographs in classical studies). London/New York: Routledge.

\section{FARÈS-DRAPEAU S.}

2005. Dédan et Lihyan. Histoire des Arabes aux confins des pouvoirs perse et hellénistique, ive-iies. avant l'ère chrétienne (Travaux de la Maison de l'Orient et de la Méditerranée). Lyon: Maison de l'Orient et de la Méditerranée. 
Version auteurs (pre-print) - J. Schiettecatte \& M. Arbach, 2016. « The political map of Arabia and the Middle East in the third century AD revealed by a Sabaean inscription », Arabian Archaeology and Epigraphy, 2016, 2: 176-196.

\section{FARIS N.A.}

1952. The book of idols being a translation from the Arabic of the Kitāb al-Așnam by Hisham Ibn-al-Kalbi. Princeton: Princeton University Press.

FIEMA Z.T., AL-JALLAD A., MACDONALD M.C.A. \& NEHMÉ L.

2015. Provincia Arabia: Nabataea, the Emergence of Arabic as a Written Language, and Graeco-Arabica. In G. Fisher (ed.), Arabs and Empires before Islam. Oxford, Oxford University Press: 373-433.

\section{FRANTSOUZOFF S}

2015. History of Hadramawt from the earliest time up to the end of the British rule. Vol. I. The history of Hadramawt in Antiquity. St Petersburg: Nestor-Historia. [In Russian with English abstract].

GAJDA I.

1996. Huğr b. 'Amr roi de Kinda et l'établissement de la domination himyarite en Arabie centrale. Proceedings of the Seminar for Arabian Studies 26: 65-73.

2004. Himyar en Arabie centrale - un nouveau document. Arabia 2: 87-98.

\section{GAWLIKOWSKI M.}

1996. Palmyra and its caravan trade. Les Annales Archéologiques Arabes Syriennes 42. Palmyra and the Silk Road. International Colloquium, Palmyra, 7-11 April 1992: 139-145.

\section{GOREA M.}

2012. Palmyra and Socotra. In I. Strauch (ed.), Foreign Sailors on Socotra. The Inscriptions and Drawings from the Cave Hoq. (Vergleichende Studien zu Antike und Orient, 3). Bremen, Hempen: 447-485.

AL-HAMDĀNĪ, ABŪ Mụ̣AMMad AL-Ḥasan/Ed. D.H. MÜLler.

1968. Șifat Jazīrat al-'Arab. Al-Hamdânî's Geographie der arabischen Halbinsel nach den Handschriften von Berlin, Constantinopel, London, Paris und Strassburg. (2 vols.) Leiden: E.J. Brill [1st ed., 1884-1891].

IBN AL-KALBī/Ed. N. ḤASAN.

1988. Nasab Ma'add wa-'l-Yaman al-kabìr. Beirut.

IBN HAZM A.A./Ed. A.M. HARUN.

1977. Jamharat ansāb al-'Arab. Cairo.

JAMME A.

1956. Un désastre Nabatéen devant Nagran. Cahiers de Byrsa 6: 165-171.

1962. Sabaean Inscriptions from Mahram Bilqis (Marib). (Publications for the American Foundation for the Study of Man III). Baltimore: The Johns Hopkins Press.

1963. The al-'Uqlah Texts. (Documentation Sud-arabe III). Washington, DC: Catholic University of America Press.

KAWATOKO M., TOKUNAGA R. \& IIZUKA M.

2005. Ancient and Islamic Rock Inscriptions of Southwest Saudi Arabia I. Wādī Khushayba. Tokyo: The Middle Eastern Culture Center in Japan and Research Institute for Languages and Cultures of Asia and Africa. 
Version auteurs (pre-print) - J. Schiettecatte \& M. Arbach, 2016. « The political map of Arabia and the Middle East in the third century AD revealed by a Sabaean inscription », Arabian Archaeology and Epigraphy, 2016, 2: 176-196.

\section{KENNEDY H. (Ed.)}

2002. Atlas historique de l'Islam. (2nd ed.). Leiden/Boston/Cologne: Brill.

KING G.

1990. The Basalt Desert Rescue Survey and some preliminary remarks on the Safaitic inscriptions and rock drawings. Proceedings of the Seminar for Arabian Studies 20: 55-78.

\section{KITCHEN K.A.}

2000. Documentation for Ancient Arabia. Part II. Bibliographical Catalogue of Texts. Liverpool, Liverpool University Press.

KROPP M.

1990. Linteau du tombeau d'Imru'-1-Qays. In A. Caubet (ed.), Aux sources du monde arabe: l'Arabie avant l'islam: collections du Musée du Louvre. Paris, Institut du monde arabe — Réunion des musées nationaux: 76-77.

LAMMENS H. \& SHAHÎD I.

1986. Lakhm. In Encyclopédie de l'Islam V. Leiden, Brill: 636.

\section{LEMAIRE A.}

1996. Histoire du Proche-Orient et chronologie sudarabique avant Alexandre. In C. Robin \& I. Gajda (eds.), Arabia Antiqua. Early origins of South Arabian states. (Serie Orientale Roma, 70/1). Rome, IsMEO: 35-48.

\section{LEVI DELLA VIDA G.}

1986. Lihyyān et Liḥyānites. II. - Dans les sources islamiques. In Encyclopédie de l'Islam V. Leiden, Brill: 769.

1995. Nizār b. Ma'add b. 'Adnān. In Encyclopédie de l'Islam VIII. Leiden, Brill: 8485.

\section{LYALL C.J.}

1918-1924. The Mufaddalīyatt. An Anthology of ancient Arabian odes compiled by alMufaddal son of Muhammad according to the recension and with the commentary of Abū Muhammad al-Qāsim Ibn Muhammad al-Anbārī. (3 vols.). Oxford: Clarendon Press.

\section{MACDONALD M.C.A.}

1994. A dated Nabataean inscription from South Arabia. In N. Nebes (ed.), Arabia Felix, Beiträge zur Sprache und Kultur des vorislamischen Arabien. Festschrift Walter W. Müller zum 60. Geburtstag. Wiesbaden, Harrassowitz: 132-141.

2000. Reflections on the linguistic map of pre-Islamic Arabia. Arabian Archaeology and Epigraphy 11: 28-79.

2004. Ancient North Arabian. In R.D. Woodard (ed.), The Cambridge Encyclopaedia of the World's Ancient Languages. Cambridge, Cambridge University Press: $488-533$.

MaCdonald M.C.A., WITH CONTRIBUTIONS FROM A. CORCElla, T. DARYAEE, G. FisheR, M. GiBBS, A. LEWIN, D. ViOlanTE \& C. Whately

2015. Arabs and Empires before the Sixth Century. In G. Fisher (ed.), Arabs and Empires before Islam. Oxford, Oxford University Press: 11-89. 
Version auteurs (pre-print) - J. Schiettecatte \& M. Arbach, 2016. « The political map of Arabia and the Middle East in the third century AD revealed by a Sabaean inscription », Arabian Archaeology and Epigraphy, 2016, 2: 176-196.

\section{MACDONALD M.C.A., AL-MU’AZZIN M. \& NEHMÉ L.}

1996. Les inscriptions safaïtiques de Syrie, cent quarante ans après leur découverte. Comptes rendus des séances de l'Académie des Inscriptions \& Belles-Lettres 1996: 435-494.

\section{MARAQTEN M.}

2014. Ḥawla al-'alāqāt mā bayna bilād al-Shām wa-l-Yaman al-Qadīm. In Z. Kafafi $\&$ M. Maraqten (ed.), A Pioneer of Arabia. Studies in the Archaeology and Epigraphic of the Levant and the Arabian Peninsula in honour of Moawiyah Ibrahim. (Rosapat 10). Rome: 97-114.

\section{MAREK C.}

1994. Der römische lnschriftenstein von Barāqish. In N. Nebes (ed.), Arabia Felix. Beiträge zur Sprache und Kultur des vorislamischen Arabien. Festschrift Walter W. Müller zum 60. Geburtstag. Wiesbaden, Harrassowitz: 178-190

MÜLLER D.H. VON

1896. Athrula. Paulys Realencyclopädie der classischen Altertumswissenschaft, II/2: 2071-2072.

MÜLLER W.W.

1974. Eine sabaeische Gesandtschaft in Ktesiphon und Seleukeia. Neue Ephemeris für Semitische Epigraphik 2: 155-165.

\section{NEBES N}

2006. Eine datierte nabatäisch-sabäische Bilingue aus Șirwāḥ. Jemen-Report 37/1: 10.

NEHMÉ L.

2009. Quelques éléments de réflexion sur Hégra et sa région à partir de $\mathrm{II}^{\mathrm{e}}$ siècle après J.-C. In J. Schiettecatte \& C.J. Robin (eds.), L'Arabie à la veille de l'Islam, bilan clinique: Table ronde tenue au Collège de France les 28 et 29 août 2006. Paris, De Boccard: 37-58.

PhiLbY H.ST.J.B. \& TRITTON A.S.

1944. Najran Inscriptions. Journal of the Royal Asiatic Society 1944, No. 2 (Oct.): 119-129.

Phillips C., VilLeNeUVE F. \& FACEY W.

2004. A Latin inscription from South Arabia. Proceedings of the Seminar for Arabian Studies 34: 239-250.

\section{PIRENNE J.}

1990. Fouilles de Shabwa I. Les témoins écrits de la région de Shabwa et l'histoire. (Bibliothèque archéologique et historique, 134). Paris, IFAPO.

PLINY.

1949-1954. Pliny's Natural History translated by H. Rackham, W.H.S. Jones \& D.E. Eichholz. Harvard/London: Harvard University Press/W. Heinemann.

\section{PROCOPIUS}

1971. Procopius. History of the Wars, Books I and II with an English translation by H.B. Dewing. London/Cambridge, MA: William Heinemann Ltd/Harvard University Press. [1st ed.: 1914]. 
Version auteurs (pre-print) - J. Schiettecatte \& M. Arbach, 2016. « The political map of Arabia and the Middle East in the third century AD revealed by a Sabaean inscription », Arabian Archaeology and Epigraphy, 2016, 2: 176-196.

PTOLEMY/ED. F.A. NOBBE.

1843-1845. Claudii Ptolemaei, Geographia. Leipzig: Tauchnitz.

RENTZ G.

1971. Hudhayl. In Encyclopédie de l'Islam III. Leiden, E.J. Brill: 559-560.

ROBIN C.J.

1986. Du nouveau sur les Yaz'anides. Proceedings of the Seminar for Arabian Studies 16: 181-197.

1996. Le royaume hujride dit 'royaume de Kinda' entre Himyar et Byzance. Comptes rendus des séances de l'Académie des Inscriptions \& Belles-Lettres 1996: 665714.

2008. Les Arabes de Himyar, des "Romains" et des Perses ( $\mathrm{III}^{\mathrm{e}}-\mathrm{VI}^{\mathrm{e}}$ siècles de l'ère chrétienne). Semitica et Classica 1: 167-202.

2012a. Matériaux pour une typologie des divinités arabiques et de leurs représentations. In I. Sachet \& C. Robin (eds.) Dieux et déesses d'Arabie. Images et représentations. (Orient \& Méditerranée, 7). Paris, De Boccard: 7118.

2012b. Appendix IV. Les Palmyréniens en Arabie du Sud. In I. Strauch (ed.), Foreign Sailors on Socotra. The Inscriptions and Drawings from the Cave Hoq. (Vergleichende Studien zu Antike und Orient ; 3). Bremen, Hempen: 488-492.

2012c. Les rois de Kinda. In A. al-Helabi, D.G. Letsios, M. al-Moraekhi \& A. alAbduljabbar (eds.), Arabia, Greece and Byzantium. Cultural Contacts in Ancient and Medieval Times. Riyadh: 59-129.

2013. Les religions pratiquées par les membres de la tribu de Kinda (Arabie) à la veille de l'Islam. Judaism ancien — Ancient Judaism 1 (2013): 203-261.

2014. Saba' et la Khawlān du Nord (Khawlān Gudādān): l'organisation et la gestion des conquêtes par les royaumes d'Arabie méridionale. In A.V. Sedov (ed.), Arabian and Islamic Studies. A Collection of Papers in Honour of Mikhail Borishovich Piotrovskij on the Occasion of His 70th Birthday. Moscow, State Museum of Oriental Studies/Institute of Oriental Studies: 156-203.

2015. Ghassān en Arabie. In D. Genequand \& C.J. Robin (eds.), Les Jafnides. Des rois arabes au service de Byzance (VI s. è. chr.). (Orient \& Méditerranée, 17). Paris, De Boccard.

ROBIN C.J. \& ARBACH M.

In press. Nouveaux jalons pour une géographie historique de la Yamāma: les toponymes mentionnés dans les inscriptions sudarabiques. In J. Schiettecatte \& A. al-Ghazzi (eds.), Al-Kharj I. Report on two excavation seasons in the oasis of al-Kharj (2011-2012), Saudi Arabia. Riyadh, Saudi Commission for Tourism and Antiquities: 101-120.

ROBIN C.J. \& GAJDA I.

1994. L'inscription du wādī 'Abadān. Raydān 6: 113-137.

ROBIN C.J. \& GOREA M.

2002. Les vestiges antiques de la grotte de Ḥoq (Suquțra, Yémen). Comptes rendus des séances de l'Académie des Inscriptions \& Belles-Lettres 2002: 409-445. 
Version auteurs (pre-print) - J. Schiettecatte \& M. Arbach, 2016. « The political map of Arabia and the Middle East in the third century AD revealed by a Sabaean inscription », Arabian Archaeology and Epigraphy, 2016, 2: 176-196.

\section{ROBIN C.J. \& TAIRAN S.}

2012. Soixante-dix ans avant l'islam: l'Arabie toute entière dominée par un roi chrétien. Comptes rendus des séances de l'Académie des Inscriptions \& BellesLettres 2012: 525-553.

\section{ROBIN C.J. \& VoGT B.}

1997. Yémen, au pays de la reine de Saba': exposition présentée à l'Institut du Monde Arabe d'oct. 1997 à fév. 1998. Paris: Flammarion.

\section{RODINSON M.}

1957. Hșstn, royaume d'Imru 1-qays. Comptes rendus du Groupe Linguistique d'Études Chamito-Sémitiques 7 (1954-1957): 114-116.

\section{ROHMER J. \& CHARLOUX G.}

2015. From Lihyān to the Nabataeans: Dating the End of the Iron Age in Northwest Arabia. Proceedings of the Seminar for Arabian Studies 45: 297-320.

\section{RYCKMANS G.}

1947. Notes épigraphiques. Quatrième série. Le Muséon 60: 149-170.

\section{SARTRE M.}

2001. D’Alexandre à Zénobie. Histoire du Levant antique, IV siècle avant J.-C.III siècle après J.-C. Paris: Fayard.

\section{SCHIETTECATTE $\mathbf{J}$.}

2011. D'Aden à Zafar: villes d'Arabie du sud préislamique. Paris: De Boccard.

2012. L'Arabie du Sud et la mer du III siècle av. au VI siècle ap. J.-C. In M.F. Boussac, J.-F. Salles \& J.-B. Yon (eds.), Autour du Périple de la mer Érythrée. (Topoi Suppl. 11). Lyon: 237-273.

\section{SEDOV A.V.}

2010. Les fouilles du secteur 6. In J.-Fr. Salles \& A.V. Sedov (eds.), Qāni'. Le port antique du Hadramawt entre la Méditerranée, l'Afrique et l'Inde. Fouilles russes 1972, 1985-1989, 1991, 1993-1994. (Indicopleustoi, Archaeologies of the Indian Ocean). Turnhout, Brepols: 183-281.

SHAHID I.

2002. Tanūkh. Encyclopédie de l'Islam X. Leiden, E.J. Brill: 206-207.

\section{AL-SHEIBA A.H.}

1987. Die Ortsnamen in den altsüdarabischen Inschriften (mit dem Versuch ihrer Identifizierung und Lokalisierung). Archäologische Berichte aus dem Yemen IV, Mainz, Verlag Philip von Zabern: 1-62.

\section{SPRENGER A}

1875. Die Alte Geographie arabiens. Bern.

\section{STRABO.}

1930. The Geography of Strabo with an English translation by Horace Leonard Jones. Vol. VII (The Loeb Classical Library). London/New York, William Heinemann Ltd/G.P. Putnam's Sons.

\section{STRENZIOK G.}

1960. Azd. Encyclopédie de l'Islam I. Leiden, E.J. Brill: 834-836. 
Version auteurs (pre-print) - J. Schiettecatte \& M. Arbach, 2016. « The political map of Arabia and the Middle East in the third century AD revealed by a Sabaean inscription », Arabian Archaeology and Epigraphy, 2016, 2: 176-196.

\section{TTABARİ/ED. NÖLDEKE T.}

1973. Geschichte der Perser und Araber zur Zeit der Sasaniden. Aus der Arabischen Chronik des Tabari übers. und mit ausführlichen Erläuterungen und Ergänzungen versehn von Th. Nöldeke. Leiden: E.J. Brill.

TARDIEU M.

1992. L'arrivée des Manichéens à al-Hīra. In P. Canivet \& J.-P. Rey-Coquais (eds.), La Syrie de Byzance à l'Islam, VII ${ }^{e}$-VIII ${ }^{e}$ siècles. Damascus: 15-24.

\section{AL-THEEB S.}

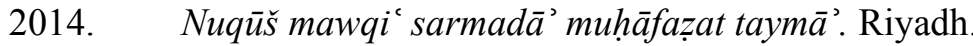

THILO U.

1958. Die Ortsnamen in der altarabischen Poesie. Ein Beitrag zur vor- und frühislamischen Dichtung und zur historischen Topographie Nordarabiens. (Schriften der Max Freiherr von Oppenheim-Stiftung, 3). Wiesbaden, Harrassowitz.

VILLENEUVE F.

2014. The Rampart and the South-Eastern Gate (Area 35). Survey and Excavation Seasons 2011 and 2014. In L. Nehmé, W. Abu-Azizeh, T. Bauzou, C. Durand, J. Rohmer, et al. Report on the Fifth Season (2014) of the Madâ'in Sâlih Archaeological Project. https://halshs.archives-ouvertes.fr/halshs-01122002: $17-75$.

VilleneuVe F., PhILliPS C. \& FACEY W.

2004. Une inscription latine de l'archipel Farasān (sud de la mer Rouge) et son contexte archéologique et historique. Arabia 2: 143-190.

WISSMANN H. VON

1964. Zur Geschichte und Landeskunde von Alt-Südarabien. (Sammlung Eduard Glaser III). Vienna: Hermann Bühlaus Nachf.

WISSMANN H. VON \& MÜLLER W.W.

1977. Das Weihrauchland Sa'kalān, Samārum und Mos-cha. (Österreichische Akademie der Wissenschaften, Sitzungsberichte, 324). Vienna: Österreichische Akademie der Wissenschaften.

WRIGHT W.

1968. The Chronicle of Joshua the Stylite composed in Syriac A.D. 507 with a translation into English and notes. Amsterdam: Philo Press.

YĀQŪT B. 'ABDALLĀH AL-RŪMĪ AL-HAMAWĪ

1866-1873. Kitāb mu'jam al-buldān. Jacut's geographisches Wörterbuch, aus den Handschriften zu Berlin, St. Petersburg, Paris, London und Oxford, herausgegeben von Ferdinand Wüstenfeld. (6 vols.) (Deutsche Morgenländische Gesellschaft, in Commission bei F. A. Brockhaus). Leipzig: F.A. Brockhaus.

\section{ZWETTLER M.J.}

1993. Imra'alqays, son of 'Amr: king of ...???. In M. Mir (ed.), Literary Heritage of Classical Islam. Arabic and Islamic Studies in Honor of James A. Bellamy. Princeton: Darwin Press: 3-37. 
Version auteurs (pre-print) - J. Schiettecatte \& M. Arbach, 2016. « The political map of Arabia and the Middle East in the third century AD revealed by a Sabaean inscription », Arabian Archaeology and Epigraphy, 2016, 2: 176-196.

2000. Ma'add in Late-Ancient Arabian Epigraphy and Other Pre-Islamic Sources.

Wiener Zeitschrift Für Die Kunde Des Morgenlandes 90 (January): 223-309. 